\title{
Quantity and distribution of methane entrapped in sediments of calcareous, Alpine glacier forefields
}

\author{
Biqing Zhu, Manuel Kübler, Melanie Ridoli, Daniel Breitenstein, and Martin H. Schroth \\ Institute of Biogeochemistry and Pollutant Dynamics, ETH Zurich, Zurich, 8092, Switzerland
}

Correspondence: Martin H. Schroth (martin.schroth@env.ethz.ch)

Received: 13 December 2019 - Discussion started: 14 January 2020

Revised: 12 May 2020 - Accepted: 17 June 2020 - Published: 10 July 2020

\begin{abstract}
Aside from many well-known sources, the greenhouse gas methane $\left(\mathrm{CH}_{4}\right)$ was recently discovered entrapped in the sediments of Swiss Alpine glacier forefields derived from calcareous bedrock. A first study performed in one glacial catchment indicated that $\mathrm{CH}_{4}$ was ubiquitous in sediments and rocks and was largely of thermogenic origin. Here, we present the results of a follow-up study that aimed at (1) determining the occurrence and origin of sedimententrapped $\mathrm{CH}_{4}$ in other calcareous glacier forefields across Switzerland and (2) providing an inventory of this sedimententrapped $\mathrm{CH}_{4}$, i.e., determining the contents and total mass of $\mathrm{CH}_{4}$ present, and its spatial distribution within and between five different Swiss glacier forefields situated on calcareous formations of the Helvetic nappes in the Central Alps.
\end{abstract}

Sediment and bedrock samples were collected at high spatial resolution from the forefields of Im Griess, Griessfirn, Griessen, Wildstrubel, and Tsanfleuron glaciers, representing different geographic and geologic regions of the Helvetic nappes. We performed geochemical analyses on gas extracted from sediments and rocks, including the determination of $\mathrm{CH}_{4}$ contents, stable carbon-isotope analyses $\left(\delta^{13} \mathrm{C}_{\mathrm{CH} 4}\right)$, and the determination of gas-wetness ratios (ratio of $\mathrm{CH}_{4}$ to ethane and propane contents). To estimate the total mass of $\mathrm{CH}_{4}$ entrapped in glacier-forefield sediments, the total volume of sediment was determined based on the measured forefield area and either literature values of mean sediment thickness or direct depth measurements using electrical resistivity tomography.

Methane was found in all sediments (0.08$73.81 \mu \mathrm{g} \mathrm{CH}_{4} \mathrm{~g}^{-1}$ dry weight) and most rocks (0.06$108.58 \mu \mathrm{g} \mathrm{CH}_{4} \mathrm{~g}^{-1}$ ) collected from the five glacier forefields, confirming that entrapped $\mathrm{CH}_{4}$ is ubiquitous in these cal- careous formations. Geochemical analyses further confirmed a thermogenic origin of the entrapped $\mathrm{CH}_{4}$ (average $\delta^{13} \mathrm{C}_{\mathrm{CH} 4}$ of sediment of $-28.23( \pm 3.42) \%$; ; average gas-wetness ratio of $75.2( \pm 48.4)$ ). Whereas sediment-entrapped $\mathrm{CH}_{4}$ contents varied moderately within individual forefields, we noted a large, significant difference in the $\mathrm{CH}_{4}$ content and total $\mathrm{CH}_{4}$ mass (range of $200-3881 \mathrm{t} \mathrm{CH}_{4}$ ) between glacier forefields at the regional scale. The lithology and tectonic setting within the Helvetic nappes appeared to be dominant factors determining rock and sediment $\mathrm{CH}_{4}$ contents. Overall, a substantial quantity of $\mathrm{CH}_{4}$ was found to be entrapped in Swiss calcareous glacier forefields. Its potential release and subsequent fate in this environment is the subject of ongoing studies.

\section{Introduction}

The atmospheric concentration of the greenhouse gas methane $\left(\mathrm{CH}_{4}\right)$ has increased from pre-industrial values of $<0.8 \mu \mathrm{LL}^{-1}$ to a current global average of $\sim 1.86 \mu \mathrm{LL}^{-1}$ (Dlugokencky, 2018), indicating an imbalance in strength between $\mathrm{CH}_{4}$ sources and sinks during this time period (Kirschke et al., 2013; Saunois et al., 2016; Ciais et al., 2013). Methane sources are commonly classified as either natural (e.g., wetlands, inland waters, and geological sources; Etiope et al., 2008; Kirschke et al., 2013; Bastviken et al., 2011), or, when they result from human activity, anthropogenic (e.g., rice paddies, livestock husbandry, fossil fuels, and biomass burning; Bousquet et al., 2006; Kirschke et al., 2013; Johnson et al., 2002; Saunois et al., 2016). An alternative way to categorize $\mathrm{CH}_{4}$ sources is based upon the $\mathrm{CH}_{4}$ production pathway: microbial, thermogenic, or abi- 
otic (Conrad, 2009; Etiope and Sherwood Lollar, 2013; Joye, 2012; Whiticar, 1999). Microbial $\mathrm{CH}_{4}$ is largely produced by methanogenic archaea (methanogens) under anoxic conditions and in the absence of energetically more favorable terminal electron acceptors as the final step of organic matter degradation (Conrad, 1996, 2009; Denman et al., 2007). However, recent evidence suggests that microbial $\mathrm{CH}_{4}$ may also be produced by certain fungi (Lenhart et al., 2012) and in oxic marine surface waters (Metcalf et al., 2012; Klintzsch et al., 2019). Conversely, thermogenic $\mathrm{CH}_{4}$ is produced in sedimentary deposits under elevated temperatures and pressures during sediment diagenesis by the thermal decomposition of organic matter (Etiope, 2012; Martini et al., 2003; Schoell, 1988). Together, microbial and thermogenic $\mathrm{CH}_{4}$ are frequently referred to as biotic $\mathrm{CH}_{4}$, as the initial substrates are of biological origin in both cases (Etiope and Sherwood Lollar, 2013). Finally, $\mathrm{CH}_{4}$ can also be formed via inorganic chemical reactions in the Earth's crust and mantle, e.g., in serpentinized, ultramafic rocks, and is therefore referred to as abiotic $\mathrm{CH}_{4}$ (Etiope and Sherwood Lollar, 2013; Etiope and Schoell, 2014; Etiope et al., 2018). Stable isotope analyses and/or analyses of gas composition are commonly employed to distinguish between microbial, thermogenic, and abiotic $\mathrm{CH}_{4}$ origins (Etiope and Schoell, 2014; Whiticar, 1999; Milkov and Etiope, 2018; Schoell, 1988).

Accelerated melting of glaciers and ice sheets as a result of global warming (Haeberli et al., 2007; Paul et al., 2004; UNEP and WGMS, 2008) has prompted intense research activities in glacial environments, including investigations on their role in the turnover of greenhouse gases. Several studies have identified subglacial environments as habitats for methanogens and, consequently, as a potentially important $\mathrm{CH}_{4}$ source (Wadham et al., 2012, 2013; Christner et al., 2012; Souchez et al., 1995; Stibal et al., 2012). Methane emissions from these locations have recently been confirmed and quantified in field measurements (Burns et al., 2018; Christiansen and Jørgensen, 2018; Lamarche-Gagnon et al., 2019). Conversely, other studies have provided evidence that aerated glacier-forefield sediments can act as a sink for atmospheric $\mathrm{CH}_{4}$ (Chiri et al., 2015; Nauer et al., 2012; Bárcena et al., 2010; Hofmann et al., 2013). This function is mediated by a group of aerobic methane-oxidizing bacteria (MOB), which catalyze $\mathrm{CH}_{4}$ oxidation at near-atmospheric concentrations (Curry, 2009; Zhuang et al., 2013; Dunfield, 2007). The strength of this $\mathrm{CH}_{4}$ sink appears to vary between different glacier-forefield landforms and increases with sediment age (Bárcena et al., 2010; Chiri et al., 2017; Hofmann et al., 2013). In this context, sediment age refers to the number of years sediment has been exposed to the atmosphere following glacier retreat. Note that both terms, sediment age and landform, serve as proxies for all edaphic variations present in these sediments at different locations within the glacier forefield. We will adopt this convention and use the terms sediment age and landform in this fashion throughout the paper.
An alternative potential $\mathrm{CH}_{4}$ source was recently detected in sediments of Swiss glacier forefields, in particular in those derived from calcareous bedrock (Nauer et al., 2012). Subsequent laboratory experiments revealed that $\mathrm{CH}_{4}$ was released from glacier-forefield sediments upon mechanical impact and during acidification (Nauer et al., 2014). In a recent study focusing on one particular Swiss glacial catchment (Wildstrubel catchment, Canton of Valais), we established that entrapped $\mathrm{CH}_{4}$ was present in nearly all sediment and bedrock samples collected throughout this area, but $\mathrm{CH}_{4}$ contents exhibited substantial variation between sampling locations (Zhu et al., 2018). We also provided robust evidence based on stable-isotope and other geochemical data that $\mathrm{CH}_{4}$ entrapped in sediment and bedrock samples was predominantly of thermogenic origin and that microbial $\mathrm{CH}_{4}$ production was likely of minor importance at this site. However, as the focus of the previous study was on the occurrence and origin of entrapped $\mathrm{CH}_{4}$ in different regions of the catchment, the number of samples collected was insufficient to rigorously assess the spatial distribution and total quantity (here defined in terms of content, i.e., concentration, and total mass) of entrapped $\mathrm{CH}_{4}$ within the forefield sediments (Zhu et al., 2018). Nevertheless, to better characterize this potential $\mathrm{CH}_{4}$ source, it is important to assess its spatial distribution and total quantity, particularly in glacier-forefield sediments, as we expect the potential for $\mathrm{CH}_{4}$ release from these sediments to far exceed that from large bedrock surfaces due to the much higher specific surface area of the former (André et al., 2009; Michel and Courard, 2014). Moreover, as calcareous glacier-forefield sediments throughout the Swiss Alps are of similar origin (Weissert and Stössel, 2015), sediment-entrapped $\mathrm{CH}_{4}$ may be a feature common to most if not all Swiss glacier forefields derived from calcareous bedrock. While this hypothesis remains to be tested, its confirmation would greatly increase the magnitude of this potential $\mathrm{CH}_{4}$ source.

Therefore, the overall goal of this study was to extend the work of Zhu et al. (2018) to other calcareous glacier forefields located in different regions of the Swiss Alps as well as to assess the distribution of entrapped $\mathrm{CH}_{4}$ contents within a glacier forefield and compare the total mass of entrapped $\mathrm{CH}_{4}$ among all sampled glacier forefields. Specific objectives included (1) testing the occurrence and origin of sediment-entrapped $\mathrm{CH}_{4}$ in four additional calcareous glacier forefields; (2) assessing the spatial distribution of the sediment-entrapped $\mathrm{CH}_{4}$ contents in detail within one glacier forefield, testing for dependencies on sediment depth, sediment age, and glacier-forefield landforms; based on results obtained from the previous step, (3) efficiently sampling sediments of the other glacier forefields to quantify the contents and total mass of sediment-entrapped $\mathrm{CH}_{4}$; and, finally, (4) upscaling these results and deriving a first estimate of the total mass of the sediment-entrapped $\mathrm{CH}_{4}$ contained in all Swiss glacier forefields situated on calcareous bedrock. 


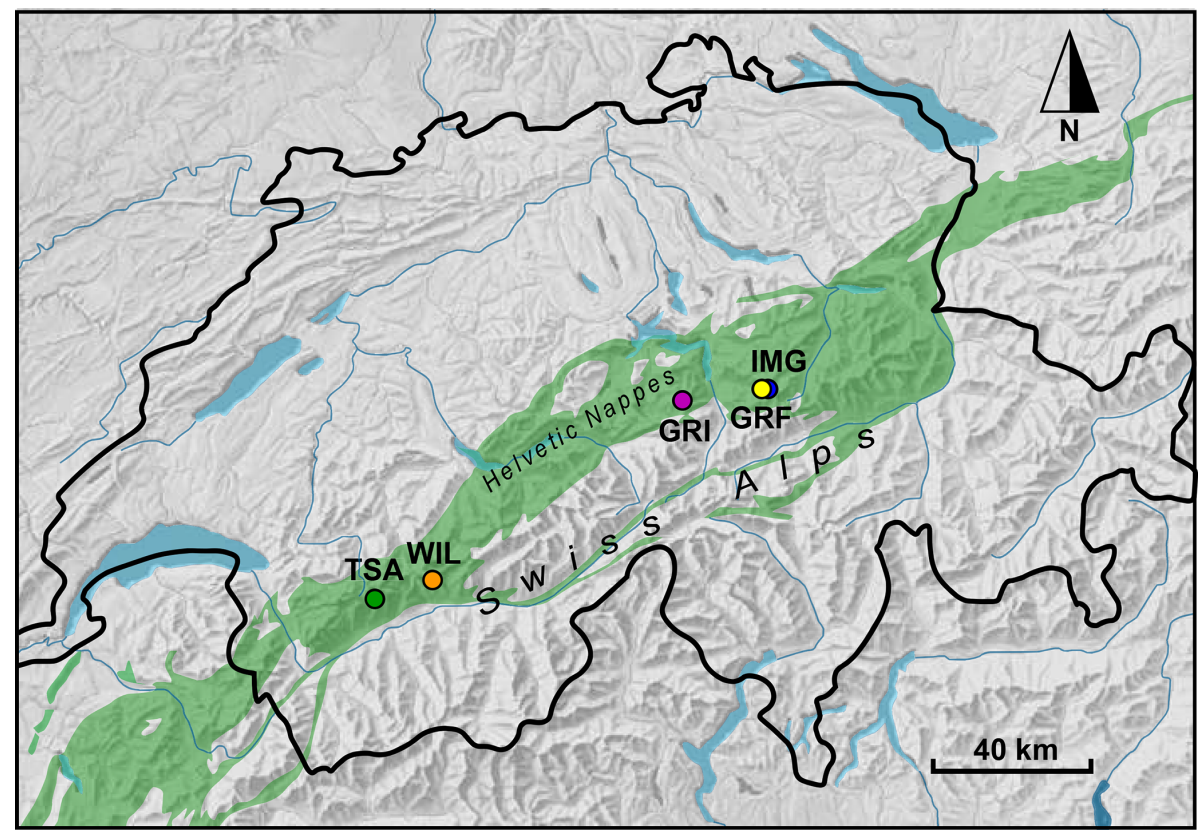

Figure 1. Map of Switzerland showing the five glacier forefields from which sediment and bedrock samples were collected: Central Switzerland, including Im Griess (IMG), Griessfirn (GRF), and Griessen (GRI); Canton of Valais, including Wildstrubel (WIL) and Tsanfleuron (TSA). All forefields are located within the Helvetic nappes (green shaded area), which consist largely of Mesozoic limestones, shales, and marls (map modified from Weissert and Stössel, 2015).

\section{Methods}

\subsection{Field sites and field work stages}

Field work was conducted in five different glacier forefields: the Im Griess (IMG), Griessfirn (GRF), and Griessen (GRI) glaciers located in Central Switzerland in the Cantons of Uri (IMG and GRF) and Obwalden (GRI), and Tsanfleuron (TSA) and the previously investigated Wildstrubel (WIL; Zhu et al., 2018) glaciers located in the Canton of Valais (Figs. 1 and S1 in the Supplement). These forefields were selected for two main reasons. Foremost, their sediments are mainly derived from the calcareous bedrock of the Helvetic nappes (green shaded area in Fig. 1), which consist of a series of nappes (sheets of thrusted rocks) largely composed of Mesozoic limestones, shales, and marls of Jurassic to Eocene age (Pfiffner, 2014; Weissert and Stössel, 2015). They were originally deposited on the shallow northern shelf of the ancient Alpine Tethys Ocean (Weissert and Mohr, 1996) and were subsequently deformed, folded, and stacked on top of each other during Alpine orogeny (Herwegh and Pfiffner, 2005). Whereas individual nappes within the Helvetic nappe system therefore share a similar origin, the lithology and tectonic settings between individual nappes can be quite diverse (Weissert and Stössel, 2015). This was suggested to be a dominant factor determining rock $\mathrm{CH}_{4}$ contents in the WIL catchment (Zhu et al., 2018). Consequently, we chose to investigate glacier forefields distant from one another (e.g., the distance from TSA to IMG is $\sim 136 \mathrm{~km}$ ), for which sediments are derived from different nappes, but also glacier forefields in close proximity to each other (e.g., the distance from IMG to GRF is $\sim 3.8 \mathrm{~km}$, and the distance from TSA to WIL is $\sim 24 \mathrm{~km}$ ), for which sediments are derived, at least in part, from the same nappe. A second important reason for the selection was that all five glacier forefields are relatively easy to access, facilitating sample collection and transport to the laboratory.

We conducted our field work in two stages. During stage I in summer 2016, we performed a detailed investigation on the spatial distribution of sediment-entrapped $\mathrm{CH}_{4}$ within a designated sampling zone at the GRF glacier forefield, using high spatial resolution sampling to determine variations in entrapped $\mathrm{CH}_{4}$ contents in relation to sediment depth, sediment age, and glacier-forefield landforms. The GRF forefield was chosen for this purpose mainly because it features well-defined sediment-age classes and well-developed, clearly distinguishable landforms within a previously discretized and characterized sampling zone (Chiri et al., 2015, 2017). We also conducted measurements of sediment thickness (distance between the ground surface and the underlying bedrock) to estimate sediment volumes and, thus, the total mass of entrapped $\mathrm{CH}_{4}$ present in these sediments. Results of the GRF field work were then used to adapt our sampling strategies for field work stage II, which was performed in summer 2017 to quantify the contents and total mass of sediment-entrapped $\mathrm{CH}_{4}$ in the IMG, GRI, TSA, 

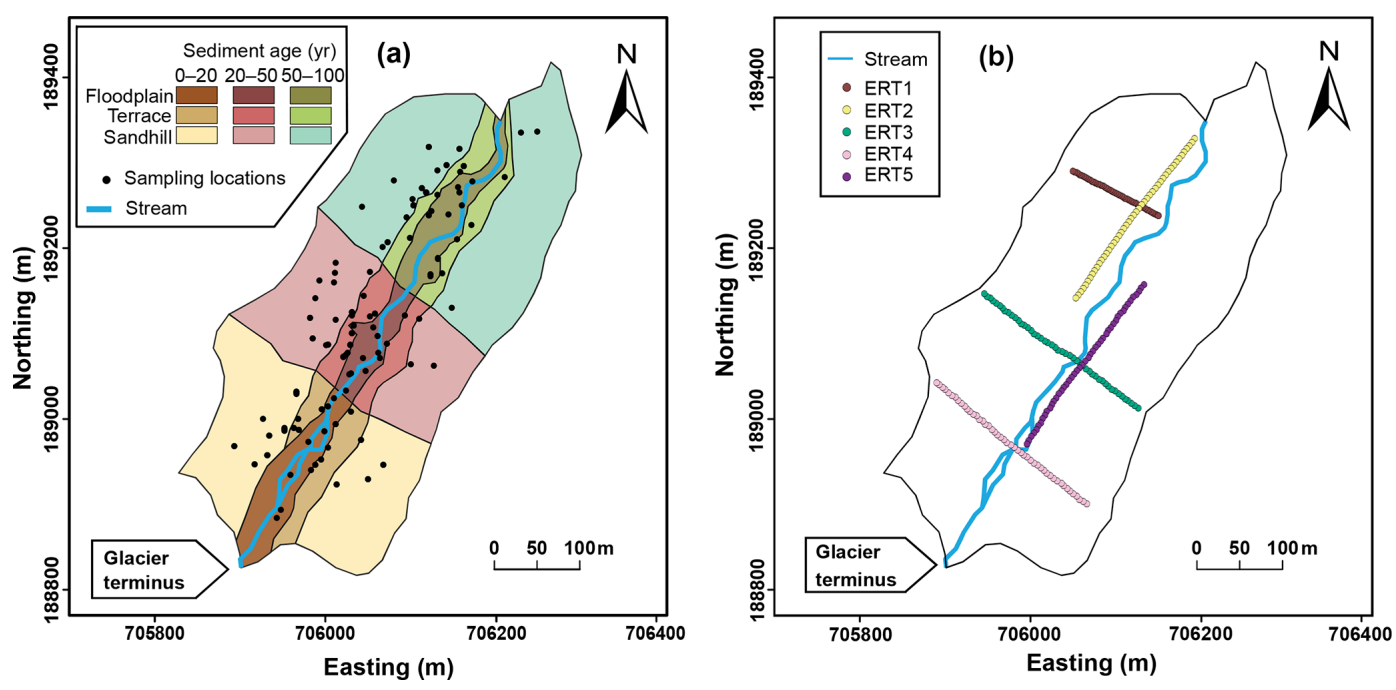

Figure 2. Sampling zone at the Griessfirn (GRF) glacier forefield showing (a) the blocks and sampling locations used to study the effect of sediment age and glacier-forefield landforms (used here as proxies for all edaphic variations present in these sediments) on entrapped $\mathrm{CH}_{4}$ contents, and (b) the locations of the five electrical resistivity tomography (ERT) profiles used to measure sediment thickness. Axes show the Swiss CH1903/LV03 coordinate system (units in meters).

and WIL glacier forefields. During both field work stages, selected sediment and rock samples were used to identify the origin of the entrapped $\mathrm{CH}_{4}$ based on $\mathrm{CH}_{4}$ stable carbonisotope analyses and analyses of entrapped gas composition (see below).

\subsubsection{Field work stage I (GRF glacier forefield)}

Sampling and measurements during stage I in the GRF forefield was conducted in three steps: first, we tested the effect of sediment depth; second, we tested the effects of sediment age and glacier-forefield landforms on entrapped $\mathrm{CH}_{4}$ contents; and, finally, we estimated the total mass of the sediment-entrapped $\mathrm{CH}_{4}$ based on the measured $\mathrm{CH}_{4}$ content, sediment thickness, and sediment-covered area.

To study the effect of sediment depth on entrapped $\mathrm{CH}_{4}$ contents, we implemented a randomized design, selecting 14 random locations within our sampling zone (not shown). We collected a total of 52 sediment samples (each $\sim 500 \mathrm{~g}$ ) by excavation from depths ranging from 20 to $70 \mathrm{~cm}$ b.s. (centimeters below the ground surface). All sediment samples were stored in clean plastic bags, transferred to the laboratory, and kept in the dark at $4{ }^{\circ} \mathrm{C}$ before further treatment. Following the extraction of entrapped gas and the subsequent quantification of $\mathrm{CH}_{4}$ contents in sediment samples (see below), the effect of sediment depth on entrapped $\mathrm{CH}_{4}$ contents was studied using a one-way ANOVA. The result of this analysis was then used to adapt the sampling scheme for the following step.

To study the effect of sediment age and glacier-forefield landforms on entrapped $\mathrm{CH}_{4}$ contents, we implemented a randomized block-sampling design. We first divided the
GRF sampling zone into nine blocks (a combination of three sediment-age classes and three landforms; Fig. 2a), using the spatial discretization of Chiri et al. (2017). The three sediment-age classes were A ( $0-20$ years), B (20-50 years), and C (50-100 years). The three forefield landforms at GRF were floodplain, terrace, and sandhills. A floodplain refers to the frequently flooded area in the immediate vicinity of the glacial stream, which commonly consists of sediments of fine particle size (mostly silt) and a lack of vegetation. A terrace refers to an elevated, previously flooded area, i.e., a former floodplain, usually featuring some vegetation coverage. Finally, sandhills consist of unoriented, hummocky glacial-debris deposits, typically featuring poorly sorted, well-aerated sediments of sandy loam to sandy clayloam texture. We collected a total of 78 sediment samples (each $\sim 500 \mathrm{~g}$ ) by excavation from a depth of $20 \mathrm{~cm}$ b.s., with 8-12 samples collected at random locations from within each block (Fig. 2a). The sampling depth of $20 \mathrm{~cm}$ b.s. was chosen based on our results from the previous step. Following laboratory analyses (see below), the impact of sediment age and landforms on entrapped $\mathrm{CH}_{4}$ contents was studied using a two-way ANOVA.

In addition to sediments, we also collected a total of 17 bedrock samples from outcrops and large boulders within the GRF glacier forefield. These samples were used to determine the $\mathrm{CH}_{4}$ content of the parent material (Zhu et al., 2018). All bedrock samples were stored in plastic bags, transferred to the laboratory, and stored in the dark at $4{ }^{\circ} \mathrm{C}$ before further treatment.

Estimation of the total mass of $\mathrm{CH}_{4}$ entrapped in glacierforefield sediments also requires information on sediment thickness. For the GRF sampling zone we employed the elec- 
trical resistivity tomography (ERT) method (e.g., Kneisel, 2006; Reynolds, 1997; Scapozza et al., 2011). Five twodimensional, vertical ERT profiles (ERT1-ERT5) were measured during two field campaigns, covering the three sediment-age classes and the three landforms (Fig. 2b). Two profiles were measured parallel to the glacier stream (ERT2 and ERT5), and three profiles were measured perpendicular to the glacier stream (ERT1, 3, and 4). For each profile, 48 stainless-steel electrodes ( $30 \mathrm{~cm}$ long, $1.2 \mathrm{~cm}$ diameter) were hammered into the sediment to a depth of $\sim 15 \mathrm{~cm}$ and connected to two 24-core copper cables, which were linked to the ERT instrument (Syscal Pro; IRIS Instruments, Orléans, France) at the profile's midpoint. To improve electrical coupling of the electrodes with the skeleton-rich glacierforefield sediments, water-soaked sponges were positioned at the sediment surface surrounding each electrode. Profile ERT1 was measured with an electrode interspacing of $2.5 \mathrm{~m}$ (total profile length $120 \mathrm{~m}$ ), whereas the other four profiles were measured with a $5 \mathrm{~m}$ distance between the electrodes (240 m profile length). Using a so-called WennerSchlumberger configuration (Loke, 2001), an electrical current was sent to the subsurface using a pair of electrodes. The voltage difference measured across the other pairs of electrodes was used to calculate the electrical resistivity of the subsurface. To infer the location of the sediment-bedrock interface, inversion of apparent resistivities was performed using the two-dimensional program RES2DINV (Loke and Barker, 1996). The average sediment thickness and its uncertainty within the GRF forefield was then analyzed in R. Electrical resistivities $>2000 \Omega \mathrm{m}$ were considered indicative of solid bedrock, whereas resistivities $<2000 \Omega$ m were considered indicative of unconsolidated sediment (Kneisel, 2006; Reynolds, 1997). The portions of the ERT profiles for which the sediment-bedrock interface could not be detected were omitted from further analyses.

\subsubsection{Field work stage II (IMG, GRI, WIL, and TSA glacier forefields)}

During stage II, we collected a total of 111 sediment samples at a depth of $20 \mathrm{~cm}$ b.s. from the glacier forefields: 25 samples from IMG, 25 samples from GRI, 33 samples from WIL, and 28 samples from TSA (sampling locations shown in Fig. 3). Based on results obtained during field work stage I and given that glacier-forefield landforms were much less prominent at IMG, GRI, WIL, and TSA, we divided each of the four forefields into six blocks and collected four to eight sediment samples (each $\sim 500 \mathrm{~g}$ ) from each block at random locations. We also collected 55 bedrock samples from outcrops and boulders at the glacier forefields: 13 samples from IMG, 14 samples from GRI, 12 samples from WIL, and 16 samples from TSA (sampling locations shown in Fig. 3).

\subsection{Laboratory procedures}

\subsubsection{Extraction of entrapped gas}

We extracted entrapped gas from sediments and rocks using the acidification method described in Nauer et al. (2014) and Zhu et al. (2018). Before acid treatment, sediments were sieved with a clean $20 \mathrm{~mm}$ mesh sieve. Particles $>20 \mathrm{~mm}$ were excluded from subsequent analyses. For each sample, $\sim 3-5 \mathrm{~g}$ of sediment was weighed and transferred into a $117 \mathrm{~mL}$ serum bottle, sealed with a butyl rubber stopper, and crimped with an aluminum cap. The vial's headspace was then flushed with $\mathrm{N}_{2}$ gas. Thereafter, $5 \mathrm{~mL}$ of deionized water was added to the vial followed by $\sim 50 \mathrm{~mL}$ of $6 \mathrm{~N}$ $\mathrm{HCl}$ to dissolve carbonate minerals. The headspace of each vial was connected to one or multiple $1 \mathrm{~L}$ gas bags (Tesseraux Spezialverpackungen $\mathrm{GmbH}$, Bürstadt, Germany). Sediment samples released large amounts of gas immediately after the acid was added. When bubbling stopped, an additional $2 \mathrm{~mL}$ of $6 \mathrm{~N} \mathrm{HCl}$ was added to each vial to confirm that the carbonate minerals were fully dissolved. Full dissolution of all carbonate minerals took $\sim 4 \mathrm{~h}$. After gas extraction, $\sim 200 \mathrm{~mL}$ of gas was removed from the gas bags with syringes and stored in glass vials for further analysis. The total volume of gas remaining in gas bags was measured with a mass-flow meter (Bronkhorst, Reinach, Switzerland). Rocks were first hammered or sawed into $\sim 1 \mathrm{~cm}$ diameter fragments and then dissolved in the same way as sediments. Initial tests, in which we compared hammering with sawing to obtain rock fragments from both the surface and the core of larger rocks, showed insignificant effects on the fragments' entrapped $\mathrm{CH}_{4}$ contents and other geochemical parameters. As the duration of the respective mechanical treatment varied greatly between the collected fragments, we consider this to be evidence that neither hammering nor sawing had an adverse effect on measured geochemical parameters.

\subsubsection{Quantification of methane, ethane, and propane}

Concentrations of $\mathrm{CH}_{4}$ were measured with a gas chromatograph equipped with a flame ionization detector (GC-FID; Trace GC Ultra, Thermo Fisher Scientific, Rodano, Italy) and a Porapak N100-120 column. The column-oven temperature was $30^{\circ} \mathrm{C}$, and the runtime was $36 \mathrm{~s}$. Nitrogen carriergas flow was set to $26 \mathrm{~mL} \mathrm{~min}^{-1}$. The FID was operated at $150{ }^{\circ} \mathrm{C}$ in high-sensitivity mode. Concentrations of ethane $\left(\mathrm{C}_{2} \mathrm{H}_{6}\right)$ and propane $\left(\mathrm{C}_{3} \mathrm{H}_{8}\right)$ were quantified in selected gas samples using the same GC-FID system but with an oven temperature of $40^{\circ} \mathrm{C}$ for $2 \mathrm{~min}$; this temperature was then increased to $140^{\circ} \mathrm{C}$ at a rate of $25^{\circ} \mathrm{Cmin}^{-1}$ before being held at a constant oven temperature of $140^{\circ} \mathrm{C}$ for another 9 min. Gas contents were calculated as the mass of $\mathrm{CH}_{4}$, $\mathrm{C}_{2} \mathrm{H}_{6}$, and $\mathrm{C}_{3} \mathrm{H}_{8}$ released during acidification, normalized to the dry weight of the sample. The dry weight of sediments was determined by the oven-drying of subsamples 


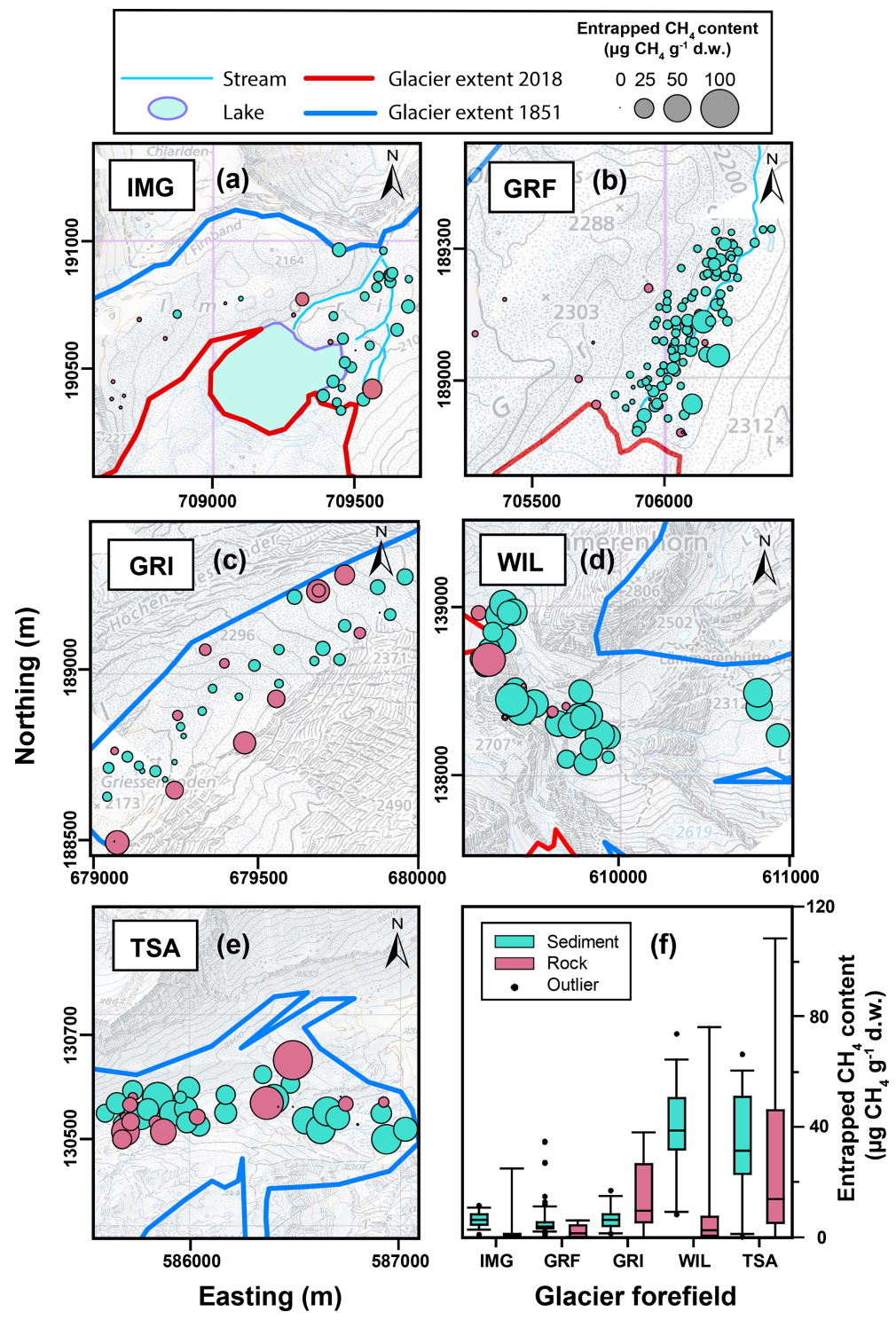

Figure 3. Spatial distribution of the entrapped $\mathrm{CH}_{4}$ contents in sediments (blue circles) and rocks (red circles) collected from the (a) Im Griess (IMG), (b) Griessfirn (GRF), (c) Griessen (GRI), (d) Wildstrubel (WIL), and (e) Tsanfleuron (TSA) glacier forefields (the circle size is proportional to the entrapped $\mathrm{CH}_{4}$ content). Background elevation data are modified from swisstopo (Swiss Federal Office of Topography; https://maps.geo.admin.ch, last access: 12 December 2019); the axes show the Swiss CH1903/LV03 coordinate system (units in meters). (f) Box and whiskers plot showing the range of entrapped $\mathrm{CH}_{4}$ contents in sediments and rocks for each glacier forefield. Boxes represent the 25th, 50th (median), and 75th percentiles; whiskers indicate the 5th and 95th percentiles; outliers are marked as dots.

at $60^{\circ} \mathrm{C}$ for $72 \mathrm{~h}$. The computed entrapped gas contents $\mathrm{C}_{\mathrm{CH} 4}, \mathrm{C}_{\mathrm{C} 2 \mathrm{H} 6}$, and $\mathrm{C}_{\mathrm{C} 3 \mathrm{H} 8}$ were subsequently used to calculate the gas-wetness ratio as follows (Jackson et al., 2013): $\mathrm{C}_{\mathrm{CH} 4} /\left(\mathrm{C}_{\mathrm{C} 2 \mathrm{H} 6}+\mathrm{C}_{\mathrm{C} 3 \mathrm{H} 8}\right)$. The gas-wetness ratio is a commonly used indicator of $\mathrm{CH}_{4}$ origin: a value of $>1000$ is considered evidence of microbial $\mathrm{CH}_{4}$, whereas a value of $\ll 1000$ is considered indicative of thermogenic $\mathrm{CH}_{4}$ (Rowe and Muehlenbachs, 1999).

\subsubsection{Stable carbon-isotope analysis of entrapped methane}

A total of 31 sediment and bedrock samples from the five glacier forefields were selected for stable carbon-isotope analysis of entrapped $\mathrm{CH}_{4}\left(\delta^{13} \mathrm{C}_{\mathrm{CH}}\right)$. To determine $\delta^{13} \mathrm{C}_{\mathrm{CH}} 4$ we used a modified acidification protocol for gas extraction, which consisted of flushing the vials' headspace with $\mathrm{He}$ instead of $\mathrm{N}_{2}$ to remove ambient air. Gas released during the acidification treatment was passed through two $1 \mathrm{M} \mathrm{NaOH}$ solutions to remove the majority of $\mathrm{CO}_{2}$, an Ascarite trap to 
remove final traces of $\mathrm{CO}_{2}$, a Drierite trap to remove $\mathrm{H}_{2} \mathrm{O}$ vapor, and a $1 \mathrm{M} \mathrm{ZnCl}_{2}$ trap to remove potential $\mathrm{H}_{2} \mathrm{~S}$ (all chemicals from Sigma Aldrich, Buchs, Switzerland). The purified gas samples were subsequently analyzed by GC-IRMS (gas chromatography isotope ratio mass spectrometry; Isoprime, Elementar UK Ltd., Stockport, UK).

\subsection{Estimation of total mass of $\mathrm{CH}_{4}$ entrapped in glacier-forefield sediments}

\subsubsection{Estimation of entrapped $\mathrm{CH}_{4}$ mass for the GRF sampling zone}

The mass of $\mathrm{CH}_{4}\left(m_{\mathrm{CH} 4}\right)$ entrapped in a specific volume of porous sediment may be calculated using the following equation:

$m_{\mathrm{CH} 4}=C_{\mathrm{CH} 4} \rho_{\text {sed }}\left[A_{\text {sed }} T_{\text {sed }}\left(1-\theta_{\mathrm{t}, \mathrm{sed}}\right)\right]$,

where $\mathrm{C}_{\mathrm{CH} 4}$ is the sediment-entrapped $\mathrm{CH}_{4}$ content (mass of $\mathrm{CH}_{4}$ per mass of sediment); $\rho_{\text {sed }}$ is the sediment-particle density; $A_{\text {sed }}$ and $T_{\text {sed }}$ are the sediment-covered area and sediment thickness in the glacier forefield, respectively; and $\theta_{\mathrm{t}, \text { sed }}$ is the total interparticle sediment porosity, hereafter referred to as sediment porosity. To determine $m_{\mathrm{CH} 4}$ for the GRF sampling zone, we applied Eq. (1) separately to each landform but also used averaged values for entrapped $\mathrm{CH}_{4}$ contents (from laboratory analyses), sediment thickness (from ERT field measurements), and sediment-covered area estimated from aerial maps (https://map.geo.admin.ch, last access: 12 December 2019). In Eq. (1), the term in brackets represents the sediment's solid volume. To compute the sediment's solid volume, we assumed a mean $\bar{\theta}_{\mathrm{t}, \text { sed }}=$ $0.42 \pm 0.02$, as determined for this site by Nauer et al. (2012). To convert solid volume to sediment mass, a mean value of $\bar{\rho}_{\text {sed }}=2.71 \pm 0.15 \mathrm{~g} \mathrm{~cm}^{-3}$ was used, as derived by Daly (1935) from measurements of a variety of calcite rock samples.

The total uncertainty in the estimated mean $\mathrm{CH}_{4}$ mass $\bar{m}_{\mathrm{CH} 4}$, expressed as the standard error (SE) of the mean $\left(\sigma_{\bar{m}_{\mathrm{CH} 4}}\right)$, was computed using the following equation:

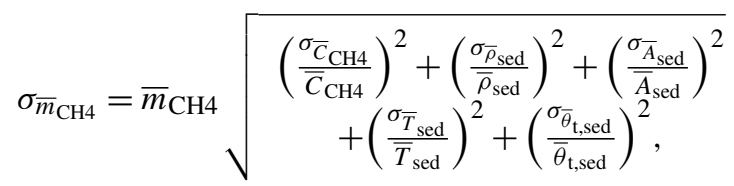

where $\sigma_{\bar{x}}$ represents the SE associated with any parameter's mean value $\bar{x}$. The individual contribution of any parameter $x$ (frac $x$, in \%) to the total uncertainty in $\bar{m}_{\mathrm{CH} 4}$ was then computed using

$\operatorname{frac}_{x}=\left(\frac{\bar{m}_{\mathrm{CH} 4}}{\sigma_{\bar{m}_{\mathrm{CH} 4}}}\left(\frac{\sigma_{\bar{x}}}{\bar{x}}\right)\right)^{2} \times 100$

We note that SE values (reported as $\bar{x} \pm \sigma_{\bar{x}}$ ) are used as a measure of uncertainty of any parameter's mean value $\bar{x}$ throughout this paper, whereas standard deviations (SD, reported as $\left.\bar{x}\left( \pm \sigma_{x}\right)\right)$ are used as a measure of general parameter variability.

\subsubsection{Estimation of entrapped $\mathrm{CH}_{4}$ mass for the five glacier forefields (IMG, GRF, GRI, WIL, and TSA)}

To compute the total mass and associated uncertainty of sediment-entrapped $\mathrm{CH}_{4}$ for all five glacier forefields, we employed Eqs. (1) and (2), although with partially modified parameters. For $\mathrm{C}_{\mathrm{CH} 4}$ we used mean values of sedimententrapped $\mathrm{CH}_{4}$ contents determined for each glacier forefield. In addition, we determined mean values $\bar{A}_{\text {sed }}$ from estimates of the maximum and minimum extents of the sediment-covered area within each glacier forefield. We used the areas exposed as a result of glacier retreat since the last glacial maximum (Little Ice Age, $\sim 1850$ ) as a maximum. These areas were estimated from the difference in glacial extent as taken from the most current (2018) and historic ( 1850) topographic maps (Swisstopo; https://map. geo.admin.ch, last access: 12 December 2019; Fig. S2). Minimum areas were directly estimated from the 2018 aerial maps. Moreover, data on sediment thickness were unavailable for the IMG, GRI, WIL, and TSA glacier forefields as well as for the GRF forefield outside of the designated sampling zone. Therefore, we used the average value of $T_{\text {sed }}=10.0 \pm 3.0 \mathrm{~m}$ obtained from our ERT measurements in the GRF sampling zone (see below) as an average $T_{\text {sed }}$ for all five glacier forefields. We note that our average $T_{\text {sed }}$ value agrees well with previous measurements performed in another Swiss glacier forefield, in which $T_{\text {sed }} \sim 8 \mathrm{~m}$ was obtained by borehole drilling (Kneisel and Kääb, 2007). Finally, we used values of $\bar{\theta}_{\mathrm{t} \text {,sed }}$ for the GRF, GRI, and WIL forefields as determined for these sites by Nauer et al. (2012). As estimates of sediment porosity were unavailable for IMG and TSA, we used $\bar{\theta}_{\mathrm{t} \text {,sed }}=0.44 \pm 0.05$ for these forefields, averaged from data reported for the five calcareous glacier forefields (Nauer et al., 2012).

\subsubsection{Estimation of entrapped $\mathrm{CH}_{4}$ mass for sediments in all Swiss glacier forefields derived from calcareous bedrock}

We again used Eqs. (1) and (2) to upscale results and to compute a first estimate of the total mass of sediment-entrapped $\mathrm{CH}_{4}$ contained in all Swiss glacier forefields derived from calcareous bedrock. In this case, we used the mean $\bar{C}_{\mathrm{CH} 4}$ of the five glacier forefields. Calcareous glacier-forefield surface area in Switzerland ( $A_{\text {sed }}$ in Eq. 1) was estimated from available data on the decrease in glaciated area in the Swiss Alps between the Little Ice Age ( 1850; Zemp et al., 2008) and the year 2010 (Fischer et al., 2014) as well as from an estimate of the fraction of calcareous bedrock area to the total area of the Swiss Alps taken from the Tectonic Map of 
Switzerland $1: 500000$ (Federal Office of Topography, swisstopo). Mean values for $\rho_{\text {sed }}, T_{\text {sed }}$, and $\theta_{\mathrm{t}, \text { sed }}$ were used as described above.

\section{Results}

\subsection{Geochemistry of gas entrapped in sediment and bedrock samples}

From the 271 sediment samples from the five glacier forefields, we analyzed 256 samples for entrapped $\mathrm{CH}_{4}$ contents. All analyzed sediments contained detectable amounts of $\mathrm{CH}_{4}$ ranging from 0.08 to $73.81 \mu \mathrm{g} \mathrm{CH}_{4} \mathrm{~g}^{-1}$ dry weight (d.w.; Fig. 3), with an average of $14.9( \pm 17.0) \mu g \mathrm{CH}_{4} \mathrm{~g}^{-1}$ d.w. Gas released from 225 samples was analyzed for $\mathrm{C}_{2} \mathrm{H}_{6}$ and $\mathrm{C}_{3} \mathrm{H}_{8}$ contents, of which 215 contained detectable amounts of $\mathrm{C}_{2} \mathrm{H}_{6}$ ranging from 0.002 to $1.67 \mu \mathrm{g} \mathrm{C}_{2} \mathrm{H}_{6} \mathrm{~g}^{-1}$ d.w., with an average of $0.25( \pm 0.32) \mu \mathrm{g} \mathrm{C}_{2} \mathrm{H}_{6} \mathrm{~g}^{-1}$ d.w. In addition, 146 out of 225 samples contained detectable amounts of $\mathrm{C}_{3} \mathrm{H}_{8}$ ranging from 0.001 to $0.82 \mu \mathrm{C} \mathrm{C}_{3} \mathrm{H}_{8} \mathrm{~g}^{-1}$ d.w., with an average of $0.11( \pm 0.15) \mu g \mathrm{C}_{3} \mathrm{H}_{8} \mathrm{~g}^{-1}$ d.w. (not shown).

The average gas-wetness ratio for all sediment samples was $75.2( \pm 48.4)$, and the average $\delta^{13} \mathrm{C}_{\mathrm{CH} 4}$ was $-28.23( \pm 3.42) \%$ o. Plotting $\delta^{13} \mathrm{C}_{\mathrm{CH} 4}$ values vs. gas-wetness ratios in a so-called Bernard diagram (Fig. 4; Bernard et al., 1978) indicated a thermogenic origin for sediment-entrapped $\mathrm{CH}_{4}$, derived from ancient terrestrial or marine organic matter (kerogen types III and II; Fig. 4). Although $\mathrm{CH}_{4}$ extracted from sediments collected in the IMG glacier forefield showed a higher variability in the gas-wetness ratios than $\mathrm{CH}_{4}$ extracted from the sediments of other glacier forefields, it still fell into the same origin type in the Bernard diagram.

All 72 bedrock samples were analyzed for $\mathrm{CH}_{4}$ content, and 64 contained detectable amounts of $\mathrm{CH}_{4}$ ranging from 0.06 to $108.58 \mu \mathrm{gCH}_{4} \mathrm{~g}^{-1}$, with an average of $11.4( \pm 20.0) \mu g \mathrm{CH}_{4} \mathrm{~g}^{-1}$ (Fig. 3). The average $\delta^{13} \mathrm{C}_{\mathrm{CH} 4}$ value of $-29.21( \pm 2.77) \%$ o was similar to that of sedimententrapped $\mathrm{CH}_{4}$. Likewise, the average gas-wetness ratio of gas extracted from rocks was $78.45( \pm 121.84)$, which is similar in value but with higher variability than gas-wetness ratios for sediment-entrapped $\mathrm{CH}_{4}$ (Fig. 4). Together, these data suggest a common, thermogenic origin of entrapped $\mathrm{CH}_{4}$ in sediments and rocks, with little apparent alteration from physical and/or chemical weathering. Moreover, our data suggest that entrapped $\mathrm{CH}_{4}$ is of similar origin in all five glacier forefields.

\subsection{Spatial distribution of sediment-entrapped $\mathrm{CH}_{4}$ contents in the GRF sampling zone}

Methane contents in 52 samples collected at depths from 20 to $70 \mathrm{~cm}$ b.s. ranged from 1.19 to $11.24 \mu \mathrm{g} \mathrm{CH} \mathrm{g}^{-1} \mathrm{~d}$.w., with one exceptionally high value at $40 \mathrm{~cm}$ b.s. (Fig. 5). Based on these data, there was no clear correlation between sediment depth and entrapped $\mathrm{CH}_{4}$ contents (one-way ANOVA,

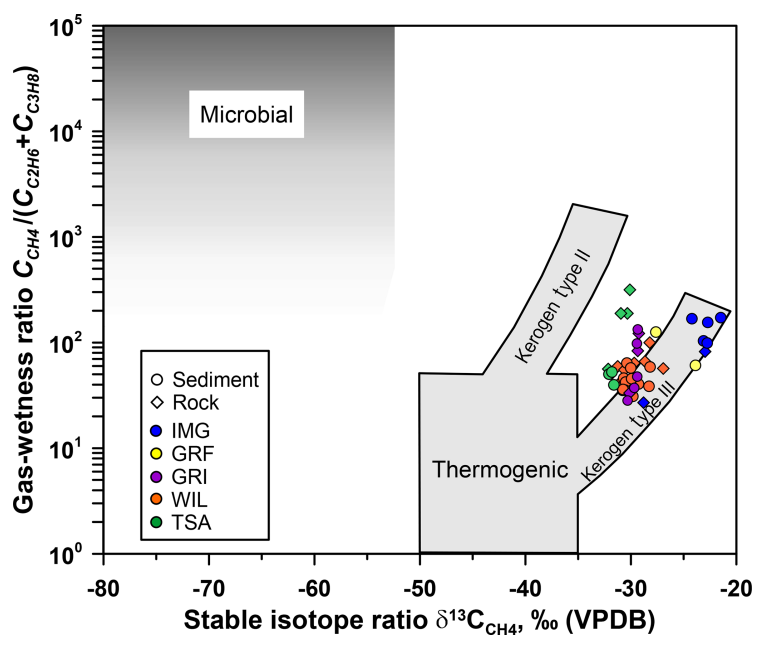

Figure 4. Adapted Bernard diagram (Bernard et al., 1978) showing the gas-wetness ratio $\left(\mathrm{C}_{\mathrm{CH} 4} /\left(\mathrm{C}_{\mathrm{C} 2 \mathrm{H} 6}+\mathrm{C}_{\mathrm{C} 3 \mathrm{H} 8}\right)\right)$ vs. $\delta^{13} \mathrm{C}_{\mathrm{CH} 4}$ for gas released from selected sediment and rock samples collected from the Im Griess (IMG), Griessfirn (GRF), Griessen (GRI), Wildstrubel (WIL), and Tsanfleuron (TSA) glacier forefields. Gray shaded areas indicate different $\mathrm{CH}_{4}$ origins (microbial vs. thermogenic).

$p=0.9$ ). Thus, we subsequently proceeded to collect sediments from $20 \mathrm{~cm}$ b.s. only, and we assumed that these samples were representative in terms of entrapped $\mathrm{CH}_{4}$ content for the entire sediment thickness.

The effects of the sediment age and landform proxies on the entrapped $\mathrm{CH}_{4}$ contents were tested using sediments collected from $20 \mathrm{~cm}$ b.s. at 99 locations (Fig. 2a). The $\mathrm{CH}_{4}$ contents in these samples ranged from 0.59 to $34.82 \mu \mathrm{g} \mathrm{CH}_{4} \mathrm{~g}^{-1}$ d.w. (Fig. 3b), with an average of $5.30( \pm 4.86) \mu \mathrm{g} \mathrm{CH}_{4} \mathrm{~g}^{-1} \mathrm{~d}$.w. Two-way ANOVA analysis indicated that landform had a significant effect on sedimententrapped $\mathrm{CH}_{4}$ contents $(p=0.03)$, whereas the effects of sediment age $(p=0.19)$ and the combined effects of sediment age and landform on entrapped $\mathrm{CH}_{4}$ contents $(p=$ 0.37 ) were insignificant. Post hoc comparisons using the Tukey HSD test indicated that mean values for the sedimententrapped $\mathrm{CH}_{4}$ content (Table 1) were significantly different between floodplain and sandhill landforms $(p=0.03)$ and were weakly different between floodplain and terrace landforms $(p=0.10)$. The difference between terrace and sandhill landforms with respect to mean sediment-entrapped $\mathrm{CH}_{4}$ content was insignificant $(p=0.88)$.

\subsection{Mass of sediment-entrapped $\mathrm{CH}_{4}$ in the GRF sampling zone}

To estimate the mass of sediment-entrapped $\mathrm{CH}_{4}$ stored within the GRF sampling zone, we used Eq. (1) with mean values of entrapped $\mathrm{CH}_{4}$ contents, sediment thickness, and sediment-covered area determined for each of the three landforms (Table 1 ). While $\bar{C}_{\mathrm{CH} 4}$ varied by a factor $<1.4$ be- 
Table 1. Mean values and uncertainties for sediment-entrapped $\mathrm{CH}_{4}$ content, sediment thickness, sediment-covered area, sediment mass, and estimated mass of entrapped $\mathrm{CH}_{4}$ in three different landforms of the Griessfirn (GRF) glacier-forefield sampling zone.

\begin{tabular}{|c|c|c|c|c|c|}
\hline Landform & $\begin{array}{l}\text { Entrapped } \mathrm{CH}_{4} \text { content } \\
\qquad{\left.\stackrel{\mu \mathrm{g} \mathrm{CH}}{4} \mathrm{~g}^{-1} \text { d.w. }\right)}_{\bar{C}_{\mathrm{CH} 4} \pm \sigma_{\bar{C}_{\mathrm{CH} 4}}^{\mathrm{a}}}\end{array}$ & $\begin{array}{r}\text { Sediment thickness } \\
\bar{T}_{\text {sed }} \pm \sigma_{\bar{T}_{\text {sed }}}\end{array}$ & $\begin{array}{l}\text { Sediment-covered } \\
\text { area }\left(\mathrm{m}^{2}\right) \\
\bar{A}_{\text {sed }} \pm \sigma_{\bar{A}_{\text {sed }}}\end{array}$ & $\begin{array}{l}\text { Sediment mass } \\
\qquad \begin{array}{l}(\mathrm{t} \text { sed. }) \\
\bar{m}_{\text {sed }} \pm \sigma_{\bar{m}_{\text {sed }}}\end{array}\end{array}$ & $\begin{array}{r}\text { Entrapped } \mathrm{CH}_{4} \text { mass } \\
(\mathrm{t} \mathrm{CH} 4) \\
\bar{m}_{\mathrm{CH} 4} \pm \sigma_{\bar{m}_{\mathrm{CH} 4}}\end{array}$ \\
\hline Floodplain & $6.37 \pm 0.55$ & $11.8 \pm 3.0$ & $2.07 \times 10^{4} \pm 2.0 \times 10^{2}$ & $3.84 \times 10^{5} \pm 1.0 \times 10^{5}$ & $2.4 \pm 0.7$ \\
\hline Terrace & $4.72 \pm 0.97$ & $12.5 \pm 4.0$ & $2.06 \times 10^{4} \pm 2.0 \times 10^{2}$ & $4.04 \times 10^{5} \pm 1.3 \times 10^{5}$ & $1.9 \pm 0.7$ \\
\hline Sandhill & $5.04 \pm 0.78$ & $6.4 \pm 3.2$ & $1.05 \times 10^{5} \pm 1.0 \times 10^{3}$ & $1.06 \times 10^{6} \pm 5.4 \times 10^{5}$ & $5.4 \pm 2.8$ \\
\hline Combined & $5.38 \pm 0.49$ & $10.2 \pm 3.0$ & $1.47 \times 10^{5} \pm 1.4 \times 10^{3}$ & $2.36 \times 10^{6} \pm 7.1 \times 10^{5}$ & $\begin{array}{r}9.7 \pm 3.0^{\mathrm{b}} \\
12.7 \pm 4.0^{\mathrm{c}}\end{array}$ \\
\hline
\end{tabular}

${ }^{a}$ Standard error of the mean (SE). ${ }^{b}$ Calculated by summing the estimated mass of entrapped $\mathrm{CH}_{4}$ from each landform. ${ }^{\mathrm{c}}$ Calculated using average values for entrapped $\mathrm{CH}_{4}$ contents, sediment thickness, and sediment-covered area.

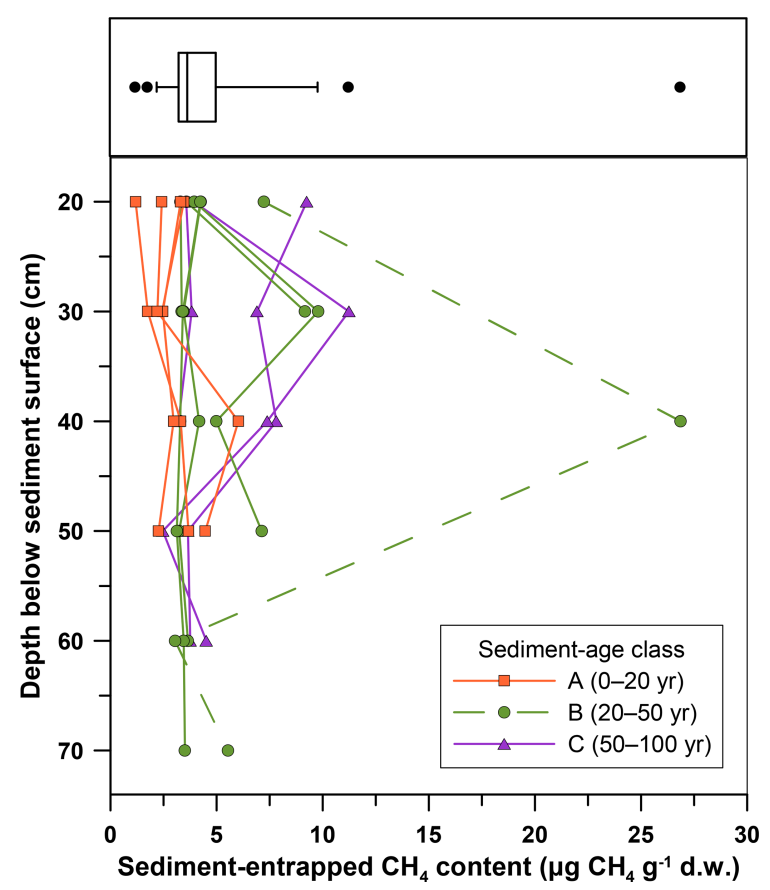

Figure 5. Sediment-entrapped $\mathrm{CH}_{4}$ contents as a function of sediment depth for samples collected in three sediment-age classes in the Griessfirn (GRF) sampling zone. The box and whiskers plot (top panel) shows the range of the entrapped $\mathrm{CH}_{4}$ contents displayed below, with the box representing the 25 th, 50th (median), and 75 th percentiles; the whiskers indicating the 5th and 95th percentiles; and the outliers marked as dots.

tween landforms, sediment thickness was highly variable along the five measured ERT profiles (range $1.0-31.5 \mathrm{~m}$; Figs. $6, \mathrm{~S} 3$ ), and $\bar{T}_{\text {sed }}$ varied by a factor of $\sim 2$ between landforms (Table 1). Sediment-covered area also showed substantial variation between the different landforms. Within the GRF sampling zone, the sandhill landform comprised the largest sediment-covered area with $\bar{A}_{\text {sed }} \approx 10^{5} \mathrm{~m}^{2}$, which was about 5 times larger than the values for floodplain and terrace landforms. Consequently, the largest sediment mass was contained in the sandhill landform (a factor 2-3 larger
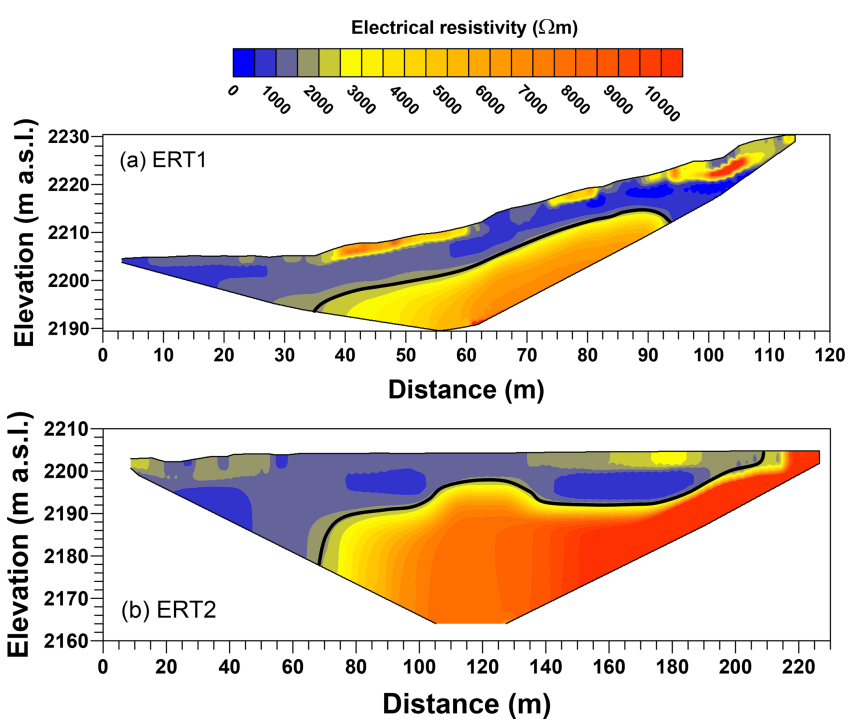

Figure 6. Vertical, two-dimensional electrical resistivity tomography (ERT) cross sections of the (a) ERT1 and (b) ERT2 profiles collected in the sampling zone of Griessfirn (GRF) glacier forefield. Solid black lines indicate the approximate location of the interface between unconsolidated sediment and the bedrock underneath. Lines were omitted at locations where the sediment-rock interface was too deep to be detected.

than floodplain and terrace; Table 1). All three landforms combined comprised a surface area of $\sim 1.5 \times 10^{5} \mathrm{~m}^{2}$ and contained an estimated mass of $\sim 2.4 \times 10^{6} \mathrm{t}$ sediment. Summing the masses of sediment-entrapped $\mathrm{CH}_{4}$ for each landform yielded a total $\bar{m}_{\mathrm{CH} 4}$ of $9.7 \pm 3.0 \mathrm{t} \mathrm{CH}_{4}$. When calculated using average values for entrapped $\mathrm{CH}_{4}$ contents and sediment thickness, as well as combined sediment-covered area, the estimated $\bar{m}_{\mathrm{CH} 4}$ within the GRF sampling zone was $12.7 \pm 4.0 \mathrm{t} \mathrm{CH}_{4}$ (last row in Table 1). Uncertainties in individual $\bar{m}_{\mathrm{CH} 4}$ values up to $\sim 50 \%$ mostly arose from uncertainties in $\bar{T}_{\text {sed }}$ (dominated by the large variability in sediment thickness across the GRF sampling zone) and to a smaller degree from uncertainties in $\bar{C}_{\mathrm{CH} 4}$. 


\subsection{Contents and total mass of sediment-entrapped $\mathrm{CH}_{4}$ in five glacier forefields}

Methane contents varied substantially between different glacier forefields (Table 2), with the distance between the forefields playing an apparently important role. Specifically, the IMG, GRF, and GRI glacier forefields are located in the northeast of the Helvetic nappes relatively close to each other (Fig. 1) and featured similar, low sediment-entrapped $\mathrm{CH}_{4}$ contents. Likewise, the WIL and TSA glacier forefields are located close to each other in the southwest of the Helvetic nappes and featured similar but high sediment-entrapped $\mathrm{CH}_{4}$ contents. Indeed, our ANOVA results indicated that differences in the sediment-entrapped $\mathrm{CH}_{4}$ contents were insignificant between the IMG, GRF, and GRI glacier forefields ( $p=0.36$ ) and between the WIL and TSA glacier forefields $(p=0.18)$. Conversely, differences in entrapped $\mathrm{CH}_{4}$ contents between the two groups of glacier forefields were highly significant $(p<0.0001)$.

The total mass of $\mathrm{CH}_{4}$ entrapped in sediments of the five glacier forefields was calculated using estimated values for sediment thickness $(10.0 \pm 3.0 \mathrm{~m}$; the thickness measured in the GRF sampling zone, see above) and sedimentparticle density $\left(2.71 \pm 0.15 \mathrm{~g} \mathrm{~cm}^{-3}\right.$; Daly, 1935) that were assumed to be identical for all five forefields, as well as specific data for each glacier forefield on entrapped $\mathrm{CH}_{4}$ contents, sediment-covered area, and sediment porosity (Table 2 ). Whereas $\bar{\theta}_{\text {t,sed }}$ values only varied slightly between the five forefields, $\bar{A}_{\text {sed }}$ varied by up to a factor of $\sim 3$ (IMG vs. WIL), and $\bar{C}_{\mathrm{CH} 4}$ varied by up to a factor of $\sim 7$ (GRF vs. WIL). This led to substantial differences in the estimated total mass of sediment-entrapped $\mathrm{CH}_{4}$ between the five forefields, which ranged from $200 \pm 74 \mathrm{t} \mathrm{CH}_{4}$ for the GRF glacier forefield to $3881 \pm 1367 \mathrm{t} \mathrm{CH}_{4}$ for the WIL forefield (Fig. 7a). Estimates of sediment-entrapped $\mathrm{CH}_{4}$ mass for the WIL and TSA glacier forefields were significantly larger than for IMG, GRF, and GRI. For all five forefields, sediment thickness and sediment-covered area contributed most to uncertainties in the quantification (Fig. 7b). Conversely, entrapped $\mathrm{CH}_{4}$ contents, sediment porosity, and sediment-particle density together contributed $\leq 16 \%$ to the calculated uncertainties.

\subsection{Mass of sediment-entrapped $\mathrm{CH}_{4}$ in all Swiss glacier forefields on calcareous bedrock}

The first estimate of the total mass of sediment-entrapped $\mathrm{CH}_{4}$ in all calcareous glacier forefields in Switzerland was based on published data on glacier retreat in the Swiss Alps, an estimation of the fraction of calcareous glacierforefield surface area, mean values for sediment thickness, sediment-particle density and sediment porosity, as well as a mean value for sediment-entrapped $\mathrm{CH}_{4}$ content obtained from the five investigated glacier forefields (18.5 $\pm 4.4 \mu \mathrm{g} \mathrm{CH}_{4} \mathrm{~g}^{-1}$ d.w.; Table 3). Between the end of the Little Ice Age $(\sim 1850)$ and 2010 , the glaciated area within the Swiss Alps has decreased by $\sim 676 \mathrm{~km}^{2}$ to less than $60 \%$ of its original value (data sources given in Table 3). When multiplied by the fraction of the calcareous bedrock area in the Swiss Alps $(54.6 \pm 1.7 \%)$, this yielded an exposed calcareous glacier-forefield area of $\sim 369 \mathrm{~km}^{2}$. The total sediment mass contained within this exposed calcareous glacier-forefield area was then computed as $5.62 \times 10^{9} \pm 1.46 \times 10^{9} \mathrm{t}$. From these numbers, we estimated the total mass of sediment-entrapped $\mathrm{CH}_{4}$ in all Swiss glacier forefields derived from calcareous bedrock to be $1.04 \times 10^{5} \pm 3.7 \times 10^{4} \mathrm{t} \mathrm{CH}_{4}$.

\section{Discussion}

\subsection{The widespread occurrence of sediment-entrapped, thermogenic $\mathrm{CH}_{4}$ in calcareous glacier forefields}

We detected substantial quantities of sediment-entrapped $\mathrm{CH}_{4}$ in all sampled glacier forefields. Entrapped $\mathrm{CH}_{4}$ was ubiquitously encountered at different sediment depths as well as in different forefield landforms and sediment-age classes. We also detected entrapped $\mathrm{CH}_{4}$ in most bedrock samples obtained from these glacial catchments. Furthermore, our data indicated that both sediment- and rock-entrapped $\mathrm{CH}_{4}$ are of thermogenic origin. Thus, the results presented here extend our previous studies (Nauer et al., 2012; Zhu et al., 2018) by providing a more detailed survey on entrapped $\mathrm{CH}_{4}$ contained in glacier-forefield sediments across the Helvetic nappes, and they support our hypothesis on its widespread occurrence and thermogenic origin in calcareous, Swiss Alpine glacier forefields. On the other hand, we cannot entirely reject the possibility of the presence of microbial $\mathrm{CH}_{4}$ sources in certain parts of glacier forefields, particularly in water-logged sediments. Methanogenic potential in isolated hot spots of water-logged sediments has previously been confirmed for the WIL glacier forefield, but it was considered to be of minor importance under field conditions (Zhu et al., 2018). In the present study, no attempt was made to specifically identify potential methanogenic hot spots in the sediments of the other four glacier forefields.

Methane is commonly found in organic-rich sedimentary rocks such as shales, marls, and limestones as a product of the thermal maturation of buried organic matter (Etiope, 2017; Horsfield and Rullkötter, 1994). Previous studies on fluid inclusions in quartz and calcite minerals collected from Alpine fissures and veins within the Helvetic nappes have revealed the existence of four fluid zones, including a large thermogenic $\mathrm{CH}_{4}$ zone (Gautschi et al., 1990; Mazurek et al., 1998; Mullis et al., 1994; Tarantola et al., 2007). The five glacier forefields that we sampled in this study were all located within or near the border of this thermogenic $\mathrm{CH}_{4}$ zone (see Fig. 1 in Tarantola et al., 2007). Thus, our results agree with previous findings on the occurrence of thermo- 
Table 2. Mean values and uncertainties of sediment-entrapped $\mathrm{CH}_{4}$ content, sediment-covered area, and total interparticle sediment porosity for the Im Griess (IMG), Griessfirn (GRF), Griessen (GRI), Wildstrubel (WIL), and Tsanfleuron (TSA) glacier forefields located within the Helvetic nappes of Switzerland. Also listed are individual nappes and major geological formations, from which glacier-forefield sediments are derived.

\begin{tabular}{|c|c|c|c|c|c|}
\hline \multirow[t]{2}{*}{$\begin{array}{l}\text { Glacier } \\
\text { forefield }\end{array}$} & \multirow{2}{*}{$\begin{array}{r}\text { Entrapped } \mathrm{CH}_{4} \\
\text { content } \\
\left(\mu \mathrm{g} \mathrm{CH} \mathrm{g}^{-1} \text { d.w. }\right) \\
\bar{C}_{\mathrm{CH} 4} \pm \sigma_{\bar{C}_{\mathrm{CH} 4}}^{\mathrm{c}}\end{array}$} & \multicolumn{2}{|l|}{$\begin{array}{r}\text { Sediment-covered } \\
\text { area }\left(\mathrm{km}^{2}\right) \\
(-)\end{array}$} & \multicolumn{2}{|r|}{ Sediment origin ${ }^{\mathrm{b}}$} \\
\hline & & $\bar{A}_{\text {sed }} \pm \sigma_{\bar{A}_{\text {sed }}}$ & $\bar{\theta}_{\mathrm{t}, \mathrm{sed}} \pm \sigma_{\bar{\theta}_{\mathrm{t}, \mathrm{sed}}}$ & Nappes & Geological formations ${ }^{\mathrm{d}}$ \\
\hline IMG & $6.51 \pm 0.56$ & $2.03 \pm 0.42$ & $0.44 \pm 0.05$ & Kammlistock & Quinten, Schrattenkalk, Stad, Zementstein \\
\hline GRF & $5.59 \pm 0.54$ & $2.27 \pm 0.40$ & $0.42 \pm 0.02$ & $\begin{array}{l}\text { Kammlistock } \\
\text { Griessstock }\end{array}$ & $\begin{array}{l}\text { Betlis, Helvetic Siliceous Limestone, } \\
\text { Öhrli, Quinten, Zementstein }\end{array}$ \\
\hline GRI & $7.03 \pm 0.91$ & $2.04 \pm 0.55$ & $0.38 \pm 0.04$ & Axen & Bommerstein, Hochstollen, Quinten \\
\hline WIL & $39.41 \pm 2.62$ & $6.35 \pm 1.01$ & $0.43 \pm 0.02$ & $\begin{array}{l}\text { Wildhorn } \\
\text { Doldenhorn }\end{array}$ & $\begin{array}{l}\text { Garschella, Öhrli, Quinten, Schilt, } \\
\text { Schrattenkalk, Seewen, Tierwis }\end{array}$ \\
\hline TSA & $33.74 \pm 3.31$ & $3.48 \pm 0.91$ & $0.44 \pm 0.05$ & $\begin{array}{l}\text { Wildhorn } \\
\text { Diablerets }\end{array}$ & $\begin{array}{l}\text { Betlis, Helvetic Siliceous Limestone, Öhrli, } \\
\text { Schrattenkalk, Tierwis, Tsanfleuron Member, } \\
\text { Pierredar }\end{array}$ \\
\hline
\end{tabular}

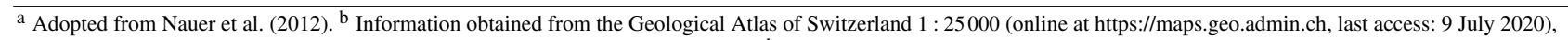
Swiss Federal Office of Topography (swisstopo). ${ }^{\mathrm{c}}$ Standard error of the mean (SE). ${ }^{\mathrm{d}}$ In alphabetical order.
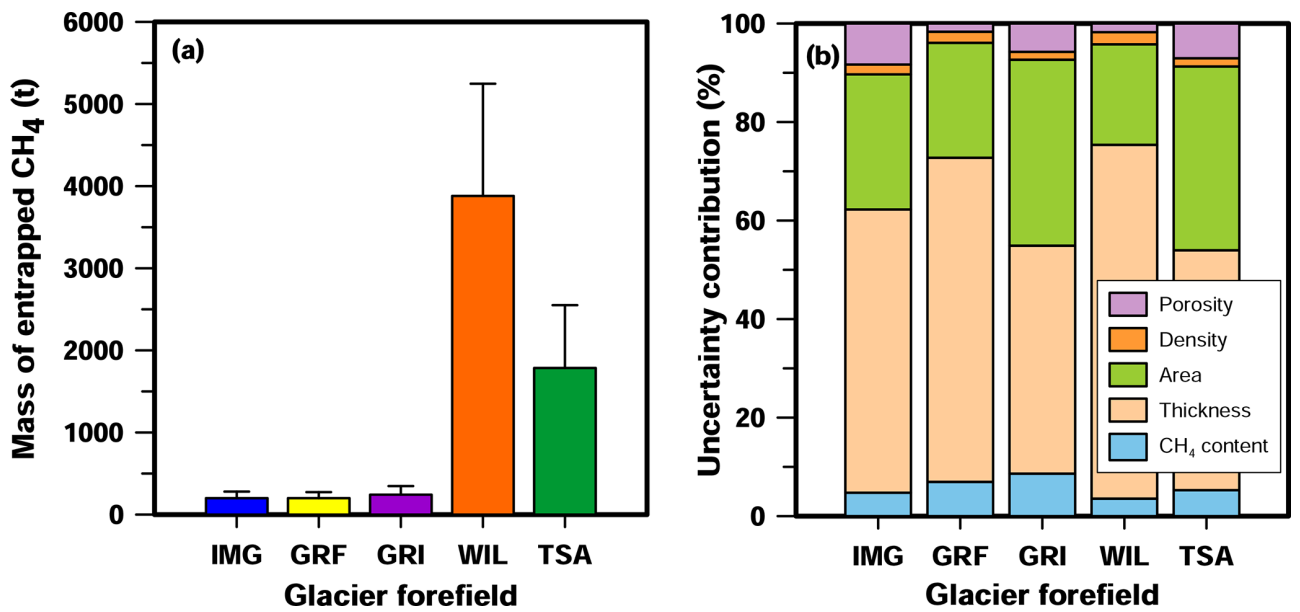

Figure 7. (a) Estimated mass of $\mathrm{CH}_{4}$ entrapped in sediments of the Im Griess (IMG), Griessfirn (GRF), Griessen (GRI), Wildstrubel (WIL), and Tsanfleuron (TSA) glacier forefields. (b) Contribution of sediment-entrapped $\mathrm{CH}_{4}$ contents, sediment thickness and area, sedimentparticle density, and sediment porosity to total uncertainties in the estimation of the mass of sediment-entrapped $\mathrm{CH}_{4}$ (error bars given in panel a) for each of the five glacier forefields.

genic $\mathrm{CH}_{4}$ in this region, including the occurrence of thermogenic $\mathrm{CH}_{4}$ detected in gas seeps near Giswil, Central Switzerland, which lies on Penninic Flysch underlain by the Helvetic nappes (Etiope et al., 2010). On the other hand, our results also show that $\mathrm{CH}_{4}$ entrapment within the Helvetic nappes is not restricted to fluid inclusions in fissure minerals and that substantial quantities of $\mathrm{CH}_{4}$ are entrapped within the matrix of the sedimentary bedrock and sediment particles themselves, presumably within inter- and intragranular micro- and macropores (Hashim and Kaczmarek, 2019; Moshier, 1989; Léonide et al., 2014; Abrams, 2017).

Our geochemical data further indicate a common origin for $\mathrm{CH}_{4}$ entrapped in bedrock and glacier-forefield sediments, derived from ancient terrestrial and marine organic matter (kerogen types III and II, respectively; Fig. 4). This provides further evidence that $\mathrm{CH}_{4}$ entrapped in the forefield sediments of the Helvetic nappes has its origin in the calcareous parent bedrock. Moreover, terrestrial and marine organic matter as the ultimate source of sediment- and rockentrapped $\mathrm{CH}_{4}$ agrees with the origin of the Helvetic nappes: their sediments and organic matter were originally deposited under highly variable climatic conditions on the shallow northern shelf of the ancient Alpine Tethys Ocean (Weissert and Mohr, 1996; Weissert and Stössel, 2015). 
Table 3. Data used for upscaling the mass of sediment-entrapped $\mathrm{CH}_{4}$ from the five sampled glacier forefields, Im Griess (IMG), Griessfirn (GRF), Griessen (GRI), Wildstrubel (WIL), and Tsanfleuron (TSA), to all calcareous glacier-forefields in Switzerland.

\begin{tabular}{lll}
\hline Parameter & Value & Data source \\
\hline Total Alpine area in Switzerland & $2.29 \times 10^{4} \pm 504 \mathrm{~km}^{2}$ & Tectonic Map of Switzerland 1: 500.000 (swisstopo) \\
Area of calcareous bedrock & $1.25 \times 10^{4} \pm 275 \mathrm{~km}^{2}$ & Tectonic Map of Switzerland 1: 500.000 (swisstopo) \\
Total glaciated area in 1850 & $1.62 \times 10^{3} \pm 36 \mathrm{~km}^{2}$ & Zemp et al. (2008) \\
Total glaciated area in 2010 & $9.44 \times 10^{2} \pm 21 \mathrm{~km}^{2}$ & Fischer et al. (2014) \\
Mean entrapped $\mathrm{CH}_{4}$ content $\left(\bar{C}_{\mathrm{CH} 4}\right)$ & $18.5 \pm 4.4 \mu \mathrm{g} \mathrm{CH} \mathrm{g}^{-1}$ d.w. & Mean of averages for the five glacier forefields \\
Mean sediment thickness $\left(\bar{T}_{\text {sed }}\right)$ & $10.0 \pm 3.0 \mathrm{~m}$ & Measurements in the GRF glacier forefield \\
Mean sediment-particle density $\left(\bar{\rho}_{\text {sed }}\right)$ & $2.71 \pm 0.15 \mathrm{~g} \mathrm{~cm}^{-3}$ & Daly (1935) \\
Mean interparticle sed. porosity $\left(\bar{\theta}_{\mathrm{t}, \mathrm{sed}}\right)$ & $0.44 \pm 0.05$ & Derived from data of Nauer et al. (2012) \\
Mass of sediment-entrapped $\mathrm{CH}_{4}\left(\bar{m}_{\mathrm{CH} 4}\right)$ & $1.04 \times 10^{5} \pm 3.7 \times 10^{4} \mathrm{t} \mathrm{CH}_{4}$ & Eq. (1), this paper \\
\hline
\end{tabular}

\subsection{Spatial distribution of sediment-entrapped $\mathrm{CH}_{4}$ within and between glacier forefields}

Sediment-entrapped $\mathrm{CH}_{4}$ contents showed moderate variability within each glacier forefield (Fig. 3a-e). As sediments were largely derived by glacial erosion from the surrounding calcareous bedrock (Chesworth et al., 2008; Fu and Harbor, 2011), the observed variability in the sediment-entrapped $\mathrm{CH}_{4}$ contents reflects the variability in the entrapped $\mathrm{CH}_{4}$ contents of the various geological formations and the associated mineralogy present in each catchment (Fig. 3f). Entrapped $\mathrm{CH}_{4}$ contents in sedimentary bedrock is typically affected by three main factors: the quantity and quality of organic matter buried during sediment deposition, the thermal history during sediment diagenesis and subsequent organic matter catagenesis, and the resulting permeability of the calcareous bedrock, which affects potential gas migration (e.g., Dayal, 2017; Horsfield and Rullkötter, 1994; Mani et al., 2017). Whereas geological formations contained within the same nappe are expected to possess a similar thermal history, the quantity and quality of organic matter buried may vary substantially between individual formations depending on prevailing conditions during the period of sediment deposition (Weissert and Mohr, 1996; Weissert et al., 1985). Thus, variability in rock- and sediment-entrapped $\mathrm{CH}_{4}$ contents is to be expected for glacial catchments featuring geological formations from different time periods, as was observed for all of the glacier forefields sampled in this study (Table 2).

Our study in the GRF forefield sampling zone indicated that sediment-entrapped $\mathrm{CH}_{4}$ content varied little with sediment depth (Fig. 5) and sediment age. However, we cannot exclude the possibility that such variations could be somewhat larger outside of the sampled depth interval, e.g., in top-layer sediments at depths $<5 \mathrm{~cm}$ as a result of enhanced chemical, physical, or biological weathering (Bernasconi et al., 2011; van der Meij et al., 2016; Lazzaro et al., 2009). We refrained from collecting top-layer sediments because they were generally much coarser in all five glacier forefields and, thus, did not appear representative of bulk sediments present at greater depth. We assume that sediment fines are continuously removed from the top layer as a result of physical (wind and water) erosion.

On the other hand, we consider the lack of significant variation with sediment age as an indication that $\mathrm{CH}_{4}$ in glacier-forefield sediments is relatively stable in its entrapped state. This hypothesis is supported by the results of our geochemical analyses for all five glacier forefields, which mostly indicated high similarity between sediment- and rockentrapped $\mathrm{CH}_{4}$ in terms of the range of measured $\mathrm{CH}_{4}$ contents (Fig. 3f), as well as gas-wetness ratios and $\delta^{13} \mathrm{C}_{\mathrm{CH}} 4$ values (Fig. 4). Thus, although sediments have undergone erosion from the parent bedrock and subsequent weathering, changes in entrapped $\mathrm{CH}_{4}$ geochemical characteristics appeared negligible. This indicates that a potential release of entrapped $\mathrm{CH}_{4}$ from sediment particles by molecular diffusion or from the oxidation of $\mathrm{CH}_{4}$ in its entrapped state within sediment particles may be small in magnitude, as these processes would be expected to cause a noticeable change in $\mathrm{CH}_{4}$ geochemical characteristics (Schloemer and Krooss, 2004; Whiticar, 1999; Zhang and Krooss, 2001). Therefore, our findings suggest that $\mathrm{CH}_{4}$ entrapped in bedrock and sediment matrices resides largely in inaccessible, occluded rather than connected pore spaces. However, a potential release of entrapped $\mathrm{CH}_{4}$ from occluded pore spaces may yet occur via sediment erosion processes, in particular by means of physical and/or chemical weathering of calcareous minerals (Emmanuel and Levenson, 2014; Ryb et al., 2014; Trudgill and Viles, 1998). As these processes act on rock surfaces, they are of great importance to sediments with large specific surface areas, with the specific surface area being inversely related to particle size (Michel and Courard, 2014). Although we are aware that similar erosion processes will act upon large bedrock surfaces, e.g., rock walls and other outcrops within glacial catchments, we have refrained from considering $\mathrm{CH}_{4}$ release from these locations (thus far) due to the much smaller specific surface areas involved. Unfortunately, the release of entrapped $\mathrm{CH}_{4}$ as a result of sediment erosion may not be detectable in the sedi- 
ment's entrapped $\mathrm{CH}_{4}$ contents, as both $\mathrm{CH}_{4}$ and sediment mass is lost as a result of erosion. Hence, our present data set yields no information on the relevance of erosion processes for $\mathrm{CH}_{4}$ release.

In contrast to sediment depth and sediment age, we detected a small but significant difference in the mean sediment-entrapped $\mathrm{CH}_{4}$ content between landforms within the GRF sampling zone. Specifically, mean entrapped $\mathrm{CH}_{4}$ content in floodplain sediments was significantly higher than in terrace and sandhill sediments (Table 1). We can only speculate about the possible reasons for this observation. One reason could be that floodplain sediments, which are intermittently removed and deposited by the glacial stream during and after flooding events, originate from locations outside of our sampling zone, i.e., from different parent bedrock (Fig. S2). Therefore, it is possible that we missed sampling parent bedrock types (e.g., from steep rock walls) with different (in this case higher) entrapped $\mathrm{CH}_{4}$ contents in this or any of the other glacial catchments. An improved mineralogical investigation of sediments in the various landforms would aid in clarifying this issue.

Finally, our data revealed large regional differences in mean sediment-entrapped $\mathrm{CH}_{4}$ contents between glacier forefields (Table 2). This may be explained by the fact that sediments in glacier forefields located in close proximity to one another are, at least in part, derived from the same individual nappes and geological formations contained therein. For example, both the WIL and TSA glacier forefields harbor sediments derived from the Wildhorn Nappe, featuring several identical geological formations. Hence, this result supports our previous hypothesis that differences in lithology, mineralogy, and tectonic settings between individual nappes play an important role in determining bedrock- and, thus, sediment-entrapped $\mathrm{CH}_{4}$ contents (Zhu et al., 2018). Regional differences in the entrapped $\mathrm{CH}_{4}$ contents paired with differences in the sediment-covered area led to significant variation in the estimates for the total mass of $\mathrm{CH}_{4}$ stored in sediments of the five glacier forefields (Fig. 7a). Uncertainties associated with these estimates were reasonably small and arose largely from uncertainties in sediment thickness and sediment-covered area (Fig. 7b). To further reduce these uncertainties, measurements of these parameters across entire glacier forefields would be of help using techniques such as geophysical methods for sediment thickness (such as the ERT method used in the GRF sampling zone) and field mapping of sediment-covered area in combination with GIS-based methods utilizing digital elevation models (e.g., Geilhausen et al., 2012; Smith and Clark, 2005; Zemp et al., 2005). Unfortunately, field measurements in the rugged alpine environment are typically time-consuming, expensive, and challenging to perform.

\subsection{A substantial quantity of sediment-entrapped $\mathrm{CH}_{4}$ with a currently unknown fate}

Our first, rough estimate of the total quantity of $\mathrm{CH}_{4}$ entrapped in sediments of all calcareous Swiss glacier forefields combined yielded a substantial mass of $1.04 \times 10^{5} \pm 3.7 \times 10^{4} \mathrm{t} \mathrm{CH}_{4}$, contained within a solid volume of $\sim 2.1 \mathrm{~km}^{3}$ glacier-forefield sediments. At first glance, this number appears large when compared with an estimate of the annual $\mathrm{CH}_{4}$ emissions to the atmosphere $\left(5.7 \times 10^{3} \mathrm{t} \mathrm{CH}_{4}\right)$ from natural and seminatural sources in Switzerland, including emissions from lakes, reservoirs, wetlands, and wild animals (Hiller et al., 2014). However, while the latter data represent annual $\mathrm{CH}_{4}$ fluxes, the fate of sediment-entrapped $\mathrm{CH}_{4}$ still remains elusive (see below). On the other hand, our number is in good agreement with a previous estimate of the $\mathrm{CH}_{4}$ content for Valanginian marl, a geological formation within the Helvetic nappes, containing calcite fracture fill $\left(\sim 0.7 \times 10^{5}-2.1 \times 10^{5} \mathrm{t} \mathrm{CH}_{4} \mathrm{~km}^{-3}\right.$ bedrock; Gautschi et al., 1990).

Our estimate for the total sediment-entrapped $\mathrm{CH}_{4}$ mass is subject to substantial uncertainty. The two largest contributors to the calculated uncertainty are the sediment-entrapped $\mathrm{CH}_{4}$ content and sediment thickness. In addition, there is considerable uncertainty in the exposed calcareous glacierforefield area, as the latter was only roughly estimated based on glacier retreat and the fraction of calcareous bedrock area in the Swiss Alps. As discussed above for individual glacier forefields, field measurements and GIS-based methods may help to reduce uncertainties related to sediment thickness and exposed area. An important way to reduce uncertainty related to the entrapped $\mathrm{CH}_{4}$ contents would be to generate a database of $\mathrm{CH}_{4}$ contents for different geological formations present within the Helvetic nappes, as lithology and tectonic settings appear to control $\mathrm{CH}_{4}$ contents. Determination of the areal extent of different geological formations would likely help to reduce uncertainties in the sediment-entrapped $\mathrm{CH}_{4}$ mass.

Whether or not sediment-entrapped $\mathrm{CH}_{4}$ plays a role as an emission source to the atmosphere will largely depend upon its rate of release from sediment particles and its potential consumption by MOB in aerated sediments. While we produced some evidence that $\mathrm{CH}_{4}$ is stable in its entrapped state (see discussion above), further investigations will be required to specifically elucidate possible mechanisms and fluxes of $\mathrm{CH}_{4}$ release in forefield sediments, in particular during periods of enhanced physical and/or chemical weathering, e.g., during rainstorms or snow melt (Winnick et al., 2017). Notably, atmospheric $\mathrm{CH}_{4}$ oxidation has previously been detected in several glacier forefields including our GRF site (Bárcena et al., 2011; Chiri et al., 2015; Hofmann et al., 2013). These studies indicated that MOB activity in forefield sediments establishes quickly (within the first 10 years after glacier retreat) and that fluxes of $\mathrm{CH}_{4}$ uptake from the atmosphere increase to values comparable with mature soils 
within a few decades (Chiri et al., 2015). Nonetheless, intermittent $\mathrm{CH}_{4}$ emissions to the atmosphere were also observed in GRF floodplain sediments (Chiri et al., 2017). Hence, we hypothesize that traces of $\mathrm{CH}_{4}$ released from sediment particles may be consumed by MOB, at least under favorable environmental conditions, and serve as an additional source of energy and carbon to this group of microorganisms. This hypothesis, of course, awaits experimental confirmation.

\section{Summary and conclusions}

Our results provide new evidence for the widespread occurrence of sediment-entrapped, thermogenic $\mathrm{CH}_{4}$ in Swiss calcareous glacier forefields. As entrapped $\mathrm{CH}_{4}$ with highly similar geochemical characteristics was also detected in most bedrock samples collected from nearby geological formations, we conclude that $\mathrm{CH}_{4}$ entrapped in forefield sediments of the Helvetic nappes has its origin in the calcareous parent bedrock. Hence, the spatial variability in the sedimententrapped $\mathrm{CH}_{4}$ contents within glacier forefields largely reflects the variability in the entrapped $\mathrm{CH}_{4}$ contents of the surrounding bedrock types.

Within glacier forefields, sediment-entrapped $\mathrm{CH}_{4}$ contents and other geochemical characteristics showed little systematic variation with sediment age and, thus, time of exposure to the atmosphere following glacier retreat. In combination with the noted similarity in geochemical characteristics, we took this finding to be evidence of the fact that $\mathrm{CH}_{4}$ in glacier-forefield sediments is relatively stable in its entrapped state, presumably because it resides in occluded pore spaces within bedrock and sediment matrices. This further indicates that $\mathrm{CH}_{4}$ entrapment within the Helvetic nappes is not restricted to fluid inclusions in fissure minerals and that substantial quantities of $\mathrm{CH}_{4}$ are entrapped within the matrix of the sedimentary bedrock and sediment particles themselves. Moreover, our results revealed large regional differences in the mean sediment-entrapped $\mathrm{CH}_{4}$ contents between glacier forefields, supporting our previous hypothesis that differences in lithology and tectonic settings between individual nappes play an important role in determining bedrockand, thus, sediment-entrapped $\mathrm{CH}_{4}$ contents.

Data availability. The data used in this paper will be made available on the ETH Zurich Research Collection repository after the article is published.

Supplement. The supplement related to this article is available online at: https://doi.org/10.5194/bg-17-3613-2020-supplement.

Author contributions. BZ, MR, MK, and MHS helped with sample collection and/or geochemical measurements and also substantially contributed to the interpretation of data. DB helped with the electrical resistivity tomography measurements and the subsequent electrical resistivity tomography data analyses. BZ and MHS wrote the paper. MHS designed the study and acquired the funding for the project. All authors commented on the paper and approved the final version of the article.

Competing interests. The authors declare that they have no conflict of interest.

Acknowledgements. We are grateful to Stefano Bernasconi (ETH Zurich) and Carsten Schubert (EAWAG; the Swiss Federal Institute of Aquatic Science and Technology) for assistance with the stable isotope analyses and to Stefano Bernasconi for providing valuable suggestions on an early version of the paper. We thank Ludovic Baron (UNIL; University of Lausanne) for initially introducing us to electrical resistivity tomography measurements in glacial systems, and we are grateful to Paul Erickson, Marco Meola, and Stefan Meyer (all ETH Zurich) for their help during the electrical resistivity tomography field campaigns. We also thank Christine, Franz, and Matthias Stadler (Altdorf, UR) for granting road access to the GRF site. We acknowledge David Archer (referee), an anonymous referee, and Tina Treude (editor) for providing valuable comments and suggestions regarding the paper.

Financial support. This research project was funded by the Swiss National Science Foundation (grant no. 200021_153571). Additional funding was received from ETH Zurich.

Review statement. This paper was edited by Tina Treude and reviewed by David Archer and one anonymous referee.

\section{References}

Abrams, M. A.: Evaluation of Near-Surface Gases in Marine Sediments to Assess Subsurface Petroleum Gas Generation and Entrapment, Geosciences, 7, 35, https://doi.org/10.3390/geosciences7020035, 2017.

André, M., Malmstrom, M. E., and Neretnieks, I.: Specific surface area determinations on intact drillcores and evaluation of extrapolation methods for rock matrix surfaces, J. Contam. Hydrol., 110, 1-8, https://doi.org/10.1016/j.jconhyd.2009.05.003, 2009.

Bárcena, T. G., Yde, J. C., and Finster, K. W.: Methane flux and high-affinity methanotrophic diversity along the chronosequence of a receding glacier in Greenland, Ann. Glaciol., 51, 23-31, 2010.

Bárcena, T. G., Finster, K. W., and Yde, J. C.: Spatial Patterns of Soil Development, Methane Oxidation, and Methanotrophic Diversity along a Receding Glacier Forefield, Southeast Greenland, Arct. Antarct. Alp. Res., 43, 178-188, https://doi.org/10.1657/1938-4246-43.2.178, 2011.

Bastviken, D., Tranvik, L. J., Downing, J. A., Crill, P. M., and Enrich-Prast, A.: Freshwater methane emissions offset the continental carbon sink, Science, 331, 50-50, 2011. 
Bernard, B. B., Brooks, J. M., and Sackett, W. M.: LightHydrocarbons in Recent Texas Continental-Shelf and Slope Sediments, J. Geophys. Res.-Oceans, 83, 4053-4061, https://doi.org/10.1029/JC083iC08p04053, 1978.

Bernasconi, S. M., Bauder, A., Bourdon, B., Brunner, I., Bunemann, E., Christl, I., Derungs, N., Edwards, P., Farinotti, D., Frey, B., Frossard, E., Furrer, G., Gierga, M., Goransson, H., Gulland, K., Hagedorn, F., Hajdas, I., Hindshaw, R., Ivy-Ochs, S., Jansa, J., Jonas, T., Kiczka, M., Kretzschmar, R., Lemarchand, E., Luster, J., Magnusson, J., Mitchell, E. A. D., Venterink, H. O., Plotze, M., Reynolds, B., Smittenberg, R. H., Stahli, M., Tamburini, F., Tipper, E. T., Wacker, L., Welc, M., Wiederhold, J. G., Zeyer, J., Zimmermann, S., and Zumsteg, A.: Chemical and Biological Gradients along the Damma Glacier Soil Chronosequence, Switzerland, Vadose Zone J., 10, 867-883, https://doi.org/10.2136/vzj2010.0129, 2011.

Bousquet, P., Ciais, P., Miller, J. B., Dlugokencky, E. J., Hauglustaine, D. A., Prigent, C., Van der Werf, G. R., Peylin, P., Brunke, E. G., Carouge, C., Langenfelds, R. L., Lathiere, J., Papa, F., Ramonet, M., Schmidt, M., Steele, L. P., Tyler, S. C., and White, J.: Contribution of anthropogenic and natural sources to atmospheric methane variability, Nature, 443, 439443, https://doi.org/10.1038/nature05132, 2006.

Burns, R., Wynn, P. M., Barker, P., McNamara, N., Oakley, S., Ostle, N., Stott, A. W., Tuffen, H., Zhou, Z., Tweed, F. S., Chesler, A., and Stuart, M.: Direct isotopic evidence of biogenic methane production and efflux from beneath a temperate glacier, Sci. Rep.-UK, 8, 17118, https://doi.org/10.1038/s41598018-35253-2, 2018.

Chesworth, W., Perez-Alberti, A., and Arnaud, E.: Ice Erosion, in: Encyclopedia of Soil Science, edited by: Chesworth, W., Springer Netherlands, Dordrecht, 333-338, 2008.

Chiri, E., Nauer, P. A., Henneberger, R., Zeyer, J., and Schroth, M. H.: Soil-methane sink increases with soil age in forefields of Alpine glaciers, Soil Biol. Biochem., 84, 83-95, https://doi.org/10.1016/j.soilbio.2015.02.003, 2015.

Chiri, E., Nauer, P. A., Rainer, E.-M., Zeyer, J., and Schroth, M. H.: High Temporal and Spatial Variability of Atmospheric-Methane Oxidation in Alpine Glacier Forefield Soils, Appl. Environ. Microb., 83, e01139-01117, 2017.

Christiansen, J. R. and Jørgensen, C. J.: First observation of direct methane emission to the atmosphere from the subglacial domain of the Greenland Ice Sheet, Sci. Rep.-UK, 8, 16623, https://doi.org/10.1038/s41598-018-35054-7, 2018.

Christner, B. C., Montross, G. G., and Priscu, J. C.: Dissolved gases in frozen basal water from the NGRIP borehole: implications for biogeochemical processes beneath the Greenland Ice Sheet, Polar Biol., 35, 1735-1741, https://doi.org/10.1007/s00300-0121198-z, 2012.

Ciais, P., Sabine, C., Bala, G., Bopp, L., Brovkin, V., Canadell, J., Chhabra, A., DeFries, R., Galloway, J., Heimann, M., Jones, C., Quéré, C. L., Myneni, R. B., Piao, S., and Thornton, P.: Carbon and Other Biogeochemical Cycles, Cambridge University Press, UK and New York, NY, USA, 2013.

Conrad, R.: Soil microorganisms as controllers of atmospheric trace gases $\left(\mathrm{H}_{2}, \mathrm{CO}, \mathrm{CH}_{4}, \mathrm{OCS}, \mathrm{N}_{2} \mathrm{O}\right.$, and $\left.\mathrm{NO}\right)$, Microbiol. Rev., 60, 609-640, 1996.
Conrad, R.: The global methane cycle: recent advances in understanding the microbial processes involved, Env. Microbiol. Rep., 1, 285-292, 2009.

Curry, C. L.: The consumption of atmospheric methane by soil in a simulated future climate, Biogeosciences, 6, 2355-2367, https://doi.org/10.5194/bg-6-2355-2009, 2009.

Daly, R. A.: Densities of rocks calculated from their chemical analyses, P. Natl. Acad. Sci. USA, 21, 657-663, https://doi.org/10.1073/pnas.21.12.657, 1935.

Dayal, A. M.: Chapter 2 - Deposition and Diagenesis, in: Shale Gas, edited by: Dayal, A. M., and Mani, D., Elsevier, Amsterdam, NL, 13-23, 2017.

Denman, K. L., Brasseur, G. P., Chidthaisong, A., Ciais, P., Cox, P. M., Dickinson, R. E., Hauglustaine, D. A., Heinze, C., Holland, E. A., and Jacob, D. J.: Couplings between changes in the climate system and biogeochemistry, in: Climate change 2007: The physical science basis, Cambridge University Press, 2007.

Dlugokencky, E. J.: Trends in Atmospheric Methane, available at: https://www.esrl.noaa.gov/gmd/ccgg/trends_ch4/, last access: 17 May 2018.

Dunfield, P. F.: The Soil Methane Sink, in: Greenhouse Gas Sinks, edited by: Reay, D., Hewitt, C. N., Smith, K. A., and Grace, J., CABI, Wallingford, UK, 152-170, 2007.

Emmanuel, S. and Levenson, Y.: Limestone weathering rates accelerated by micron-scale grain detachment, Geology, 42, 751-754, https://doi.org/10.1130/G35815.1, 2014.

Etiope, G.: Climate science: Methane uncovered, Nat Geosci., 5, 373-374, https://doi.org/10.1038/ngeo1483, 2012.

Etiope, G.: Natural Gas, in: Encyclopedia of Geochemistry: A Comprehensive Reference Source on the Chemistry of the Earth, edited by: White, W. M., Springer International Publishing, Cham, 1-5, 2017.

Etiope, G. and Schoell, M.: Abiotic Gas: Atypical, But Not Rare, Elements, 10, 291-296, https://doi.org/10.2113/gselements.10.4.291, 2014.

Etiope, G. and Sherwood Lollar, B.: Abiotic methane on earth, Rev. Geophys., 51, 276-299, https://doi.org/10.1002/rog.20011, 2013.

Etiope, G., Lassey, K. R., Klusman, R. W., and Boschi, E.: Reappraisal of the fossil methane budget and related emission from geologic sources, Geophys. Res. Lett., 35, L09307, https://doi.org/10.1029/2008GL033623, 2008.

Etiope, G., Zwahlen, C., Anselmetti, F. S., Kipfer, R., and Schubert, C. J.: Origin and flux of a gas seep in the Northern Alps (Giswil, Switzerland), Geofluids, 10, 476-485, https://doi.org/10.1111/j.1468-8123.2010.00302.x, 2010.

Etiope, G., Ifandi, E., Nazzari, M., Procesi, M., Tsikouras, B., Ventura, G., Steele, A., Tardini, R., and Szatmari, P.: Widespread abiotic methane in chromitites, Sci. Rep.-UK, 8, 8728, https://doi.org/10.1038/s41598-018-27082-0, 2018.

Fischer, M., Huss, M., Barboux, C., and Hoelzle, M.: The new Swiss Glacier Inventory SGI2010: relevance of using high-resolution source data in areas dominated by very small glaciers, Arct. Antarct. Alp. Res., 46, 933-945, https://doi.org/10.1657/1938-4246-46.4.933, 2014.

Fu, P. and Harbor, J.: Glacial Erosion, in: Encyclopedia of Snow, Ice and Glaciers, edited by: Singh, V. P., Singh, P., and Haritashya, U. K., Springer Netherlands, Dordrecht, 332-341, 2011. 
Gautschi, A., Faber, E., Meyer, J., Mullis, J., Schenker, F., and Ballentine, C.: Hydrocarbon and noble gases in fluid inclusions of alpine calcite veins: implications for hydrocarbon exploration, Bulletin der Vereinigung Schweizerischer Petroleum-Geologen und-Ingenieure, 57, 13-36, 1990.

Geilhausen, M., Otto, J. C., and Schrott, L.: Spatial distribution of sediment storage types in two glacier landsystems (Pasterze \& Obersulzbachkees, Hohe Tauern, Austria), J. Maps, 8, 242-259, https://doi.org/10.1080/17445647.2012.708540, 2012.

Haeberli, W., Hoelzle, M., Paul, F., and Zemp, M.: Integrated monitoring of mountain glaciers as key indicators of global climate change: the European Alps, Ann. Glaciol., 46, 150-160, https://doi.org/10.3189/172756407782871512, 2007.

Hashim, M. S. and Kaczmarek, S. E.: A review of the nature and origin of limestone microporosity, Mar. Petrol. Geol., 107, 527554, https://doi.org/10.1016/j.marpetgeo.2019.03.037, 2019.

Herwegh, M. and Pfiffner, O. A.: Tectono-metamorphic evolution of a nappe stack: A case study of the Swiss Alps, Tectonophysics, 404, 55-76, https://doi.org/10.1016/j.tecto.2005.05.002, 2005.

Hiller, R. V., Bretscher, D., DelSontro, T., Diem, T., Eugster, W., Henneberger, R., Hobi, S., Hodson, E., Imer, D., Kreuzer, M., Künzle, T., Merbold, L., Niklaus, P. A., Rihm, B., Schellenberger, A., Schroth, M. H., Schubert, C. J., Siegrist, H., Stieger, J., Buchmann, N., and Brunner, D.: Anthropogenic and natural methane fluxes in Switzerland synthesized within a spatially explicit inventory, Biogeosciences, 11, 1941-1959, https://doi.org/10.5194/bg-11-1941-2014, 2014.

Hofmann, K., Reitschuler, C., and Illmer, P.: Aerobic and anaerobic microbial activities in the foreland of a receding glacier, Soil Biol. Biochem., 57, 418-426, https://doi.org/10.1016/j.soilbio.2012.08.019, 2013.

Horsfield, B. and Rullkötter, J.: Diagenesis,Catagenesis, and Metagenesis of Organic Matter, in: The Petroleum System - From Source to Trap, edited by: Magoon, L. B. and Dow, W. G., AAPG Memoir, Tulsa, OK, USA, 189-200, 1994.

Jackson, R. E., Gorody, A. W., Mayer, B., Roy, J. W., Ryan, M. C., and Van Stempvoort, D. R.: Groundwater protection and unconventional gas extraction: the critical need for fieldbased hydrogeological research, Ground Water, 51, 488-510, https://doi.org/10.1111/gwat.12074, 2013.

Johnson, D., Phetteplace, H., and Seidl, A.: Methane, nitrous oxide and carbon dioxide emissions from ruminant livestock production systems, in: Proceedings of the 1st International Conference on Greenhouse Gases and Animal Agriculture, Obihiro, Japan, 7-11 November 2001, 77-85, 2002.

Joye, S. B.: A piece of the methane puzzle, Nature, 491, 538, https://doi.org/10.1038/nature11749, 2012.

Kirschke, S., Bousquet, P., Ciais, P., Saunois, M., Canadell, J. G., Dlugokencky, E. J., Bergamaschi, P., Bergmann, D., Blake, D. R., Bruhwiler, L., Cameron-Smith, P., Castaldi, S., Chevallier, F., Feng, L., Fraser, A., Heimann, M., Hodson, E. L., Houweling, S., Josse, B., Fraser, P. J., Krummel, P. B., Lamarque, J.F., Langenfelds, R. L., Le Quere, C., Naik, V., O’Doherty, S., Palmer, P. I., Pison, I., Plummer, D., Poulter, B., Prinn, R. G., Rigby, M., Ringeval, B., Santini, M., Schmidt, M., Shindell, D. T., Simpson, I. J., Spahni, R., Steele, L. P., Strode, S. A., Sudo, K., Szopa, S., van der Werf, G. R., Voulgarakis, A., van Weele, M., Weiss, R. F., Williams, J. E., and Zeng, G.: Three decades of global methane sources and sinks, Nat. Geosci., 6, 813-823, https://doi.org/10.1038/ngeo1955, 2013.

Klintzsch, T., Langer, G., Nehrke, G., Wieland, A., Lenhart, K., and Keppler, F.: Methane production by three widespread marine phytoplankton species: release rates, precursor compounds, and potential relevance for the environment, Biogeosciences, 16, 4129-4144, https://doi.org/10.5194/bg-16-4129-2019, 2019.

Kneisel, C.: Assessment of subsurface lithology in mountain environments using 2D resistivity imaging, Geomorphology, 80, 3244, https://doi.org/10.1016/j.geomorph.2005.09.012, 2006.

Kneisel, C. and Kääb, A.: Mountain permafrost dynamics within a recently exposed glacier forefield inferred by a combined geomorphological, geophysical and photogrammetrical approach, Earth Surf. Proc. Land., 32, 1797-1810, https://doi.org/10.1002/esp.1488, 2007.

Lamarche-Gagnon, G., Wadham, J. L., Lollar, B. S., Arndt, S., Fietzek, P., Beaton, A. D., Tedstone, A. J., Telling, J., Bagshaw, E. A., and Hawkings, J. R.: Greenland melt drives continuous export of methane from the ice-sheet bed, Nature, 565, 73, https://doi.org/10.1038/s41586-018-0800-0, 2019.

Lazzaro, A., Abegg, C., and Zeyer, J.: Bacterial community structure of glacier forefields on siliceous and calcareous bedrock, Eur. J. Soil Sci., 60, 860-870, https://doi.org/10.1111/j.13652389.2009.01182.x, 2009.

Lenhart, K., Bunge, M., Ratering, S., Neu, T. R., Schuttmann, I., Greule, M., Kammann, C., Schnell, S., Muller, C., Zorn, H., and Keppler, F.: Evidence for methane production by saprotrophic fungi, Nat. Commun., 3, 1046, https://doi.org/10.1038/ncomms2049, 2012.

Léonide, P., Fournier, F., Reijmer, J. J. G., Vonhof, H., Borgomano, J., Dijk, J., Rosenthal, M., van Goethem, M., Cochard, J., and Meulenaars, K.: Diagenetic patterns and pore space distribution along a platform to outer-shelf transect (Urgonian limestone, Barremian-Aptian, SE France), Sediment. Geol., 306, 123, https://doi.org/10.1016/j.sedgeo.2014.03.001, 2014.

Loke, M.: Tutorial: 2-D and 3-D Electrical Imaging Surveys, Course Notes for USGS Workshop "2-D and 3-D Inversion and Modeling of Surface and Borehole Resistivity Data", Storrs, CT, USA, 13-16 March 2001, 2001.

Loke, M. H. and Barker, R. D.: Rapid least-squares inversion of apparent resistivity pseudosections by a quasiNewton method, Geophys. Prospect., 44, 131-152, https://doi.org/10.1111/j.1365-2478.1996.tb00142.x, 1996.

Mani, D., Kalpana, M. S., Patil, D. J., and Dayal, A. M.: Chapter 3 Organic Matter in Gas Shales: Origin, Evolution, and Characterization, in: Shale Gas, edited by: Dayal, A. M. and Mani, D., Elsevier, Amsterdam, NL, 25-54, 2017.

Martini, A. M., Walter, L. M., Ku, T. C., Budai, J. M., McIntosh, J. C., and Schoell, M.: Microbial production and modification of gases in sedimentary basins: A geochemical case study from a Devonian shale gas play, Michigan basin, AAPG Bull, 87, 1355-1375, https://doi.org/10.1306/031903200184, 2003.

Mazurek, M., Water, H., and Gautschi, A.: Hydrocarbon gases and fluid evolution in very low-grade metamorphic terranes: A case study from the Central Swiss Alps, in: Water-Rock Interaction, edited by: Arehart, G. B. and Hulston, J. R., Balkema, Rotterdam, NL, 417-420, 1998.

Metcalf, W. W., Griffin, B. M., Cicchillo, R. M., Gao, J. T., Janga, S. C., Cooke, H. A., Circello, B. T., Evans, B. S., Martens- 
Habbena, W., Stahl, D. A., and van der Donk, W. A.: Synthesis of Methylphosphonic Acid by Marine Microbes: A Source for Methane in the Aerobic Ocean, Science, 337, 1104-1107, https://doi.org/10.1126/science.1219875, 2012.

Michel, F. and Courard, L.: Particle Size Distribution of Limestone Fillers: Granulometry and Specific Surface Area Investigations, Particul. Sci. Technol., 32, 334-340, https://doi.org/10.1080/02726351.2013.873503, 2014.

Milkov, A. V. and Etiope, G.: Revised genetic diagrams for natural gases based on a global dataset of $>20,000$ samples, Org Geochem, 125, 109-120, https://doi.org/10.1016/j.orggeochem.2018.09.002, 2018.

Moshier, S. O.: Microporosity in Micritic Limestones - a Review, Sediment. Geol., 63, 191-213, https://doi.org/10.1016/00370738(89)90132-2, 1989.

Mullis, J., Dubessy, J., Poty, B., and Oneil, J.: Fluid Regimes during Late Stages of a Continental Collision - Physical, Chemical, and Stable-Isotope Measurements of Fluid Inclusions in Fissure Quartz from a Geotraverse through the Central Alps, Switzerland, Geochim. Cosmochim. Ac., 58, 2239-2267, https://doi.org/10.1016/0016-7037(94)90008-6, 1994.

Nauer, P. A., Dam, B., Liesack, W., Zeyer, J., and Schroth, M. H.: Activity and diversity of methane-oxidizing bacteria in glacier forefields on siliceous and calcareous bedrock, Biogeosciences, 9, 2259-2274, https://doi.org/10.5194/bg-9-2259-2012, 2012.

Nauer, P. A., Chiri, E., Zeyer, J., and Schroth, M. H.: Technical Note: Disturbance of soil structure can lead to release of entrapped methane in glacier forefield soils, Biogeosciences, 11, 613-620, https://doi.org/10.5194/bg-11-613-2014, 2014.

Paul, F., Kääb, A., Maisch, M., Kellenberger, T., and Haeberli, W.: Rapid disintegration of Alpine glaciers observed with satellite data, Geophys. Res. Lett., 31, L21402, https://doi.org/10.1029/2004GL020816, 2004.

Pfiffner, O. A.: Geology of the Alps, 2nd edn., Wiley Blackwell, Chichester, West Sussex, UK, 376 pp., 2014.

Reynolds, J. M.: An Introduction to Applied and Environmental Geophysics, John Wiley \& Sons, Chichester, England, 1997.

Rowe, D. and Muehlenbachs, A.: Low-temperature thermal generation of hydrocarbon gases in shallow shales, Nature, 398, 61-63, https://doi.org/10.1038/18007, 1999.

Ryb, U., Matmon, A., Erel, Y., Haviv, I., Katz, A., Starinsky, A., Angert, A., and Team, A.: Controls on denudation rates in tectonically stable Mediterranean carbonate terrain, Geol. Soc. Am. Bull., 126, 553-568, https://doi.org/10.1130/B30886.1, 2014.

Saunois, M., Bousquet, P., Poulter, B., Peregon, A., Ciais, P., Canadell, J. G., Dlugokencky, E. J., Etiope, G., Bastviken, D., Houweling, S., Janssens-Maenhout, G., Tubiello, F. N., Castaldi, S., Jackson, R. B., Alexe, M., Arora, V. K., Beerling, D. J., Bergamaschi, P., Blake, D. R., Brailsford, G., Brovkin, V., Bruhwiler, L., Crevoisier, C., Crill, P., Covey, K., Curry, C., Frankenberg, C., Gedney, N., Höglund-Isaksson, L., Ishizawa, M., Ito, A., Joos, F., Kim, H.-S., Kleinen, T., Krummel, P., Lamarque, J.-F., Langenfelds, R., Locatelli, R., Machida, T., Maksyutov, S., McDonald, K. C., Marshall, J., Melton, J. R., Morino, I., Naik, V., O’Doherty, S., Parmentier, F.-J. W., Patra, P. K., Peng, C., Peng, S., Peters, G. P., Pison, I., Prigent, C., Prinn, R., Ramonet, M., Riley, W. J., Saito, M., Santini, M., Schroeder, R., Simpson, I. J., Spahni, R., Steele, P., Takizawa, A., Thornton, B. F., Tian, H., Tohjima, Y., Viovy, N., Voulgarakis, A., van Weele, M., van der Werf, G.
R., Weiss, R., Wiedinmyer, C., Wilton, D. J., Wiltshire, A., Worthy, D., Wunch, D., Xu, X., Yoshida, Y., Zhang, B., Zhang, Z., and Zhu, Q.: The global methane budget 2000-2012, Earth Syst. Sci. Data, 8, 697-751, https://doi.org/10.5194/essd-8-697-2016, 2016.

Scapozza, C., Lambiel, C., Baron, L., Marescot, L., and Reynard, E.: Internal structure and permafrost distribution in two alpine periglacial talus slopes, Valais, Swiss Alps, Geomorphology, 132, 208-221, https://doi.org/10.1016/j.geomorph.2011.05.010, 2011.

Schloemer, S. and Krooss, B. M.: Molecular transport of methane, ethane and nitrogen and the influence of diffusion on the chemical and isotopic composition of natural gas accumulations, Geofluids, 4, 81-108, https://doi.org/10.1111/j.14688123.2004.00076.x, 2004.

Schoell, M.: Multiple origins of methane in the Earth, Chem. Geol., 71, 1-10, https://doi.org/10.1016/0009-2541(88)90101-5, 1988.

Smith, M. J., and Clark, C. D.: Methods for the visualization of digital elevation models for landform mapping, Earth Surf. Proc. Land., 30, 885-900, https://doi.org/10.1002/esp.1210, 2005.

Souchez, R., Lemmens, M., and Chappellaz, J.: Flowinduced mixing in the GRIP basal ice deduced from the $\mathrm{CO}_{2}$ and $\mathrm{CH}_{4}$ records, Geophys. Res. Lett., 22, 41-44, https://doi.org/10.1029/94GL02863, 1995.

Stibal, M., Wadham, J. L., Lis, G. P., Telling, J., Pancost, R. D., Dubnick, A., Sharp, M. J., Lawson, E. C., Butler, C. E. H., Hasan, F., Tranter, M., and Anesio, A. M.: Methanogenic potential of Arctic and Antarctic subglacial environments with contrasting organic carbon sources, Glob. Change Biol., 18, 33323345, https://doi.org/10.1111/j.1365-2486.2012.02763.x, 2012.

Tarantola, A., Mullis, J., Vennemann, T., Dubessy, J., and de Capitani, C.: Oxidation of methane at the $\mathrm{CH}_{4} / \mathrm{H}_{2} \mathrm{O}-\left(\mathrm{CO}_{2}\right)$ transition zone in the external part of the Central Alps, Switzerland: Evidence from stable isotope investigations, Chem. Geol., 237, 329-357, https://doi.org/10.1016/j.chemgeo.2006.07.007, 2007.

Trudgill, S. T. and Viles, H. A.: Field and laboratory approaches to limestone weathering, Q. J. Eng. Geol. Hydroge., 31, 333-341, https://doi.org/10.1144/Gsl.Qjeg.1998.031.P4.06, 1998.

UNEP, and WGMS: Global glacier changes: facts and figures, United Nations Environment Programme and World Glacier Monitoring Service, Geneva, Switzerland, 88 pp., 2008.

van der Meij, W. M., Temme, A. J. A. M., de Kleijn, C. M. F. J. J., Reimann, T., Heuvelink, G. B. M., Zwoliński, Z., Rachlewicz, G., Rymer, K., and Sommer, M.: Arctic soil development on a series of marine terraces on central Spitsbergen, Svalbard: a combined geochronology, fieldwork and modelling approach, SOIL, 2, 221-240, https://doi.org/10.5194/soil-2-221-2016, 2016.

Wadham, J. L., Arndt, S., Tulaczyk, S., Stibal, M., Tranter, M., Telling, J., Lis, G. P., Lawson, E., Ridgwell, A., Dubnick, A., Sharp, M. J., Anesio, A. M., and Butler, C. E. H.: Potential methane reservoirs beneath Antarctica, Nature, 488, 633-637, https://doi.org/10.1038/nature11374, 2012.

Wadham, J. L., De'ath, R., Monteiro, F. M., Tranter, M., Ridgwell, A., Raiswell, R., and Tulaczyk, S.: The potential role of the Antarctic Ice Sheet in global biogeochemical cycles, Earth Env. Sci. T. R. So., 104, 55-67, https://doi.org/10.1017/s1755691013000108, 2013. 
Weissert, H. and Mohr, H.: Late Jurassic climate and its impact on carbon cycling, Palaeogeogr Palaeocl, 122, 27-43, https://doi.org/10.1016/0031-0182(95)00088-7, 1996.

Weissert, H. and Stössel, I.: Der Ozean im Gebirge - Eine geologische Zeitreise durch die Schweiz (in German), 3rd edn., vdf Hochschulverlag AG, ETH Zurich, Zurich, Switzerland, 2015.

Weissert, H. J., McKenzie, J. A., and Channell, J. E. T.: Natural Variations in the Carbon Cycle During the Early Cretaceous, in: The Carbon Cycle and Atmospheric $\mathrm{CO}_{2}$ : Natural Variations Archean to Present, edited by: Sundquist, E. T. and Broecker, W. S., 32, 531-545, https://doi.org/10.1029/GM032p0531, 1985.

Whiticar, M. J.: Carbon and hydrogen isotope systematics of bacterial formation and oxidation of methane, Chem. Geol., 161, 291314, https://doi.org/10.1016/S0009-2541(99)00092-3, 1999.

Winnick, M. J., Carroll, R. W. H., Williams, K. H., Maxwell, R. M., Dong, W. M., and Maher, K.: Snowmelt controls on concentration-discharge relationships and the balance of oxidative and acid-base weathering fluxes in an alpine catchment, East River, Colorado, Water Resour. Res., 53, 2507-2523, https://doi.org/10.1002/2016wr019724, 2017.

Zemp, M., Kaab, A., Hoelzle, M., and Haeberli, W.: GIS-based modelling of glacial sediment balance, Z. Geomorphol. Supp., 138, 113-129, https://doi.org/10.5167/uzh-40580, 2005.
Zemp, M., Paul, F., Hoelzle, M., and Haeberli, W.: Glacier Fluctuations in the European Alps, 1850-2000, in: Darkening Peaks Glacier Retreat, Science, and Society, edited by: Orlove, B., Wiegandt, E., and Luckman, B. H., University of California Press, Oakland, CA, USA, 296, 2008.

Zhang, T. W. and Krooss, B. M.: Experimental investigation on the carbon isotope fractionation of methane during gas migration by diffusion through sedimentary rocks at elevated temperature and pressure, Geochim. Cosmochim. Ac., 65, 2723-2742, https://doi.org/10.1016/S0016-7037(01)00601-9, 2001.

Zhu, B., Henneberger, R., Weissert, H., Zeyer, J., and Schroth, M. H.: Occurrence and Origin of Methane Entrapped in Sediments and Rocks of a Calcareous, Alpine Glacial Catchment, J. Goephys. Res.-Biogeo., 123, 3633-3648, https://doi.org/10.1029/2018JG004651, 2018.

Zhuang, Q., Chen, M., Xu, K., Tang, J., Saikawa, E., Lu, Y., Melillo, J. M., Prinn, R. G., and McGuire, A. D.: Response of global soil consumption of atmospheric methane to changes in atmospheric climate and nitrogen deposition, Global Biogeochem. Cy., 27, 650-663, https://doi.org/10.1002/gbc.20057, 2013. 